NBER WORKING PAPER SERIES

\title{
THE IMPACT OF LENGTH OF THE SCHOOL YEAR ON STUDENT PERFORMANCE AND EARNINGS: EVIDENCE FROM THE GERMAN SHORT SCHOOL YEARS
}

\author{
Jorn-Steffen Pischke \\ Working Paper 9964 \\ http://www.nber.org/papers/w9964
NATIONAL BUREAU OF ECONOMIC RESEARCH
1050 Massachusetts Avenue
Cambridge, MA 02138
September 2003

I thank Josh Angrist, David Autor, Jens Ludwig, Jack Porter, Justin Wolfers, and participants at various seminars for helpful comments. I thank Stefan Bender for calculating the social security statistics used in the paper for me. Some of the data used in this paper have been obtained from the German Zentralarchiv für Empirische Sozialforschung at the University of Köln (ZA). Neither the producers of the data nor the ZA bear any responsibility for the analysis and interpretation of the data in this paper. The views expressed herein are those of the authors and not necessarily those of the National Bureau of Economic Research.

(C)2003 by Jorn-Steffen Pischke. All rights reserved. Short sections of text, not to exceed two paragraphs, may be quoted without explicit permission provided that full credit, including ${ }^{C}$ notice, is given to the source. 
The Impact of Length of the School Year on Student Performance and Earnings: Evidence from the German Short School Year

Jorn-Steffen Pischke

NBER Working Paper No. 9964

September 2003

JEL No. J24, J31

\section{$\underline{\text { ABSTRACT }}$}

This paper investigates how changing the length of the school year, leaving the basic curriculum unchanged, affects learning and subsequent earnings. I use variation introduced by the WestGerman short school years in 1966-67, which exposed some students to a total of about two thirds of a year less of schooling while enrolled. I show that the short school years led indeed to shorter schooling for affected students. Using comparisons across cohorts, states, and secondary school tracks, I find that the short school years increased grade repetition in primary school, but had no adverse effect on the number of students attending the highest secondary school track or earnings later in life.

Jorn-Steffen Pischke

Centre for Economic Performance

London School of Economics

Houghton Street

London WC2A $2 \mathrm{AE}$

England

and NBER

s.pischke@1se.ac.uk 


\section{Introduction}

Primary and secondary school students in the United States attend school on average for 180 days, compared to an OECD average of 195 days and 208 days in East Asian countries. ${ }^{1}$ Because of its concerns about the performance of American students, extending the length of the school year was a major policy recommendation of a 1983 presidential commission in its report "A Nation at Risk." The role of time as an educational input became an even bigger focus of a second commission a decade later, in a report entitled "Prisoners of Time." Despite the important role of time in school in the policy debate there is little evidence to what degree the length of the school year matters for academic achievement and later earnings of students. In this paper, I study the impact of a reform in the West-German school system in 196667 which dramatically changed the amount of instructional time for some students in school at the time without directly affecting the curriculum, the highest grade completed, or the secondary school degree received by these students. I use this as a natural experiment to study the effects of time spent in school on grade repetition, the choice of the secondary school track attended, and on later earnings.

Until the 1960s, all German states except Bavaria started the school year in spring. Politicians felt at the time that it was more sensible to start the school year after summer vacation, and they wanted to achieve uniformity in this policy across states. The transition to a fall start of the school year was achieved in most states through two short school years with 24 instead of the regular 37 weeks of instruction each. Students in school during this time therefore lost a total of 26 weeks of instruction, about two thirds of a school year. The city states of West-Berlin and Hamburg opted for a single long school year instead. The state of Niedersachsen, although introducing the short school years, added extra time to graduating classes, so that many students in this state did not loose any time in school, even though they participated in the short school years. This means that there is substantial

\footnotetext{
${ }^{1}$ See NCES (2000) and Lee and Barro (2001).
} 
heterogeneity across birth cohorts and states in who was exposed to less schooling because of the short school years.

I use variation across cohorts, states, and the secondary school track attended by a student to identify the effect of participating in the short school years on a variety of outcomes. While the short school years nominally eliminated about two thirds of a year, the total time affected students spent in school may actually have been reduced by less. Some students may have stayed in school longer, for example because of grade repetition or other compensatory mechanisms. This is an important aspect, which has to be kept in mind when assessing policies which try to manipulate term length. I analyze grade repetition among primary school students directly and show that the short school years did indeed have the effect that more students were held back. Unlike grade repetition, which is a relevant outcome only for weaker students, the short school years did not seem to have had a negative effect on the proportion of students entering the highest secondary school track. Finally, I also fail to find negative effects on earnings later in life.

These results may seem surprising in light of the evidence showing that returns to schooling are quite substantial. ${ }^{2}$ The association between earnings and schooling may not be causal, of course, because individuals select the amount of schooling they obtain partly on the basis of unobserved characteristics, which also affect earnings. To overcome this problem, many recent studies have used instrumental variables to estimate the returns to schooling, exploiting compulsory schooling laws or differences in the costs of schooling for particular individuals. While these studies should be free of ability bias, they have typically found even larger returns than the OLS estimates. In the United States these estimates are clustered around 10 percent; see Card (1999) for a survey of this literature.

These estimates of returns to schooling may not be the correct comparison when trying to interpret the impact of reducing term length on student

\footnotetext{
${ }^{2}$ Acemoglu and Pischke (1999) report OLS returns to schooling of 7 to 8 percent for Germany during the 1980s. US returns were slightly lower than that at the beginning of the decade and higher at the end.
} 
achievement and earnings. Most importantly, the variation underlying the results on returns to schooling comes from the highest grade completed or degree obtained. The short school years, on the other hand, affected the length of schooling obtained without affecting secondary degrees obtained directly. One plausible explanation for the differing results would therefore be that returns to schooling estimated previously reflect mostly the signalling value of schooling, which is tied to degrees, rather than actual human capital accumulation, which is related to the time spent in school. The short school years had the same impact on the time in school for all affected students, therefore not altering the relative costs of different degrees or their signalling value. If this interpretation is correct, the length of the school year might easily be reduced in many advanced countries where the minimum level of schooling obtained by all students is high. ${ }^{3}$

However, the results may also be consistent with schooling reflecting mostly human capital accumulation. It has to be kept in mind that the nominal curriculum did not change for students exposed to the short school years. Teachers might have been able to actually teach all the relevant material in a reduced amount of time. Universities and post-secondary vocational schools might have compensated for material that had been missed in school. Individuals exposed to the short school years graduated earlier and hence spent more time in the labor market. The increased incidence of grade repetition might indicate that slower students were not able to cope with the increased pace during the short school years. Grade repetition might have been a mechanism that insured that some marginal students learned the same amount.

Nevertheless, this interpretation would also suggest that reducing time students spent in school would be socially beneficial, since overall resources are being saved without adverse effects on the labor market performance of students. My results would fail to carry over to broader policies if the short

\footnotetext{
${ }^{3}$ Note that changing the length of the school year for a given level of compulsory schooling has different implications in the signalling model than changing the compolsory schooling age. See Lang and Kropp (1986) for evidence from compulsory schooling laws on the signalling hypothesis.
} 
school years brought about particular effort from educators and students, which was specific to this episode and could not be sustained in a more normal setting. Unfortunately, it is difficult to obtain firm evidence on whether this was the case.

There are a number of previous results on the effects of term length on student achievement and earnings. Various studies on school quality in the United States include term length at the school level as one of the regressors (for example, Grogger, 1997, Eide and Showalter, 1998). These studies typically find insignificant effects of term length on achievement and earnings. One problem with the school level studies is that term length may proxy for other school attributes, which are unobserved in these equations. But the most important shortcoming is probably that there simply is not very much variation in the length of the school year across schools.

Rizzuto and Wachtel (1980), Card and Krueger (1992), and Betts and Johnson (1998) examined the effect of state level policies, often for earlier periods where there was more variation in term length. The effect of unobserved heterogeneity may also be less of an issue with state level data. All three studies found positive and significant effects of term length on later earnings when state effects are not controlled for. Card and Krueger also present results controlling for state effects. The positive effect of term length vanishes within states and conditional on other school quality variables. While some of the findings by Card and Krueger have been challenged by Heckman, Layne-Farrar, and Todd (1996), the zero term length result is relatively robust in their re-estimations.

Lee and Barro (2001) correlate student performance across countries with a variety of measures for school resources, among them the amount of time spent in school during the year. They find no effects of the length of the school year on internationally comparable test scores. ${ }^{4}$ A more recent study by Wößmann (2003), which also analyzes cross country test score data, corroborates this finding. He finds a significant effect of instructional time, but

\footnotetext{
${ }^{4}$ The results differ somewhat by subject of the test: longer time in school increased mathematics and science scores, but lowered reading scores.
} 
the size of the effect is negligible. A 10 percent reduction in the time of instruction (a larger change than that implied by the German short school years) leads to drop in test scores of 0.015 standard deviations. Lee and Barro (2001) also look at grade repetition, and they find a significant effect of more instructional time. These results therefore largely agree with my findings on the German short school years. None of these previous studies exploits policy induced variation in the length of the school year of the magnitude which I study here, which makes the German experience one of particular interest. There are three German studies of the impact of the short school years on student achievement by Meister (1972), Schlevoigt, Hebbel and Richtberg (1968) and Thiel (1973), which I will discuss in some detail below.

The remainder of the paper is organized as follows. Section 2 starts by laying out some background about the German school system and the short

school years, and discusses what type of variation is used for identification of the short school year effects. It also discusses the measurement framework, and assesses the external validity of the exercise. Section 3 describes the data sources used to obtain the empirical results in Section 4 on the time spent in school, learning outcomes, earnings, and civic outcomes. Conclusions are drawn in Section 5.

\section{Institutions and Empirical Framework}

\subsection{Background on the German School System and Identification}

In the 1930s, the German school year started uniformly after Easter. When new territories were integrated into the country due to Nazi expansion after 1937, heterogeneity arose because some of these areas started their school year in summer. The Ministry for Science and Education therefore decreed in 1941 to move the beginning of the school year to summer for all of Germany.

Education has been in the political domain of the federal states in post- 
war West-Germany. After the war, all states except Bavaria eventually returned to the pre-war custom of starting school in spring. This heterogeneity caused frictions, for example, when families moved across state borders and children had to switch schools. Therefore, the prime ministers of the states signed an Agreement on the Unification of the School System in 1964, the so called Hamburg Accord (Hamburger Abkommen). Among other provisions, the agreement stipulated to move the start of the school year uniformly to summer again, so that the new school year would commence after the summer vacation. ${ }^{5}$ The accord was to be implemented by the beginning of the 1967 school year.

A heated debate ensued on how to accomplish the transition from a start of the school year after Easter to the new date in summer. An early consensus emerged among the states, which was based on a prolonged school year, lasting from April 1966 to summer of 1967. This solution was supposed to avoid that children in school during this time would graduate with having attended for a shorter period than what is required by law. However, the Hamburg Accord had also stipulated that schooling is compulsory up to at least grade 9 . Some, predominantly southern, states had only required 8 grades in the basic secondary school track, while 9 years were already common in the northern states. Various of these states, for example Rheinland-Pfalz, decided to use the 1966-67 transition period to introduce the 9th grade as well. To do this, they planned to split the April 1966 to summer 1967 period into two short school years. This way, the cohort of students entering 7th grade in April 1966 and not attending higher secondary schools, could graduate after nominally attending nine grades by summer 1967, even though they only spent 8 years and four months in school.

The early consensus of a long school year unraveled as more and more states decided to opt for the short school years. Eight states carried out the transition by having a short school year starting April 1, 1966 and ending November 30, 1966, and a second short school year starting December 1, 1966

\footnotetext{
${ }^{5}$ Summer vacations are staggered across German states, so that the beginning of the new school year can be anywhere from beginning of August until middle of September.
} 
and ending July 31, $1967 .{ }^{6}$ The two city states of West-Berlin and Hamburg stuck to the solution with a single long school year. Starting in 1967, the school year would begin in August and end in July in these states. Graduating classes which participated in the long school year, however, would graduate at the end of March after a shortened final year. Hence, everybody in Hamburg and Berlin attended school for the regular amount of time despite the transition. Bavaria, which already started in summer, had a regular length school year during the transition period. Finally, Niedersachsen adopted the short school years during 1966-67 but added additional school periods in subsequent years for some types of schools (see below for details).

The mechanics of the transition lead to variation in the length of schooling along a variety of dimensions, which can be used for identification. Since the two short school years involved 24 instead of the regular 37 weeks of instruction, students in school during 1966-67 lost a total of 26 weeks in class, and therefore graduated after having attended school for about two thirds of a year less than other students who either completed their schooling by 1966 or began school in 1967 or later. Hence, cohorts which graduated before 1966 or which entered after 1967 went to school longer than cohorts in school during 1966-67. Throughout the analysis, I will not use this variation alone, because I want to control for cohort main effects.

The second dimension is due to the fact that students in Germany attend one of three secondary school tracks, each of which is of a different length. The lowest track is basic school (Volksschule or later Hauptschule), which ended with the end of compulsory schooling after 8 or 9 grades. ${ }^{7}$ The second track, middle school (Realschule), ends after grade 10, and the highest track, Gymnasium, leads to graduation after 13 grades. This means that some students, who were born in the late 1940s and were close to graduation by the mid-60s, will have been affected by the short school years and not others, depending on which track of secondary school they attended. For example,

\footnotetext{
${ }^{6}$ These are the nominal starting and ending dates of the school years. The second short school year effectively ended with the beginning of summer vacation at varying dates across states.

${ }^{7}$ States only started introducing 10 th grades in basic school in later periods.
} 
consider someone born in 1949 and entering school in 1956. This person will have graduated by spring 1966 if she went to basic or middle school but will have been in school during both short school years if she went to Gymnasium. The interaction of cohort and track helps identify the effects of the short school year, and is used in my analysis.

The third dimension is the contrasts across states. This makes use of the fact that Bavaria, Hamburg, and Berlin did not have short school years. The state of Niedersachsen provides an additional source of variation. Niedersachsen decided not to have students enter 1st grade for the school year starting December 1966, but only in August 1967. This decision freed up resources (class rooms and teachers) which were used to lengthen the final school year for students attending basic and middle school in the subsequent years. Every basic school cohort entering 9th grade between 1966 and 1974, had an additional 8 month period added to their last school year. For example, the cohort, which entered 9th grade in April 1966 (the first short school year), did not graduate until March 1967. The next cohort, entering 9th grade in December 1966, graduated in March 1968 and so on. Thus, all basic school students attended school for 9 years, even those who were in school during the short school years.

Things were slightly more complicated for middle school students. The students entering 10th grade in April 1966 graduated in November 1966 after 9 years and 8 months. The next three cohorts, entering 10th grade between December 1966 and August 1968, graduated after 9 years and 4 months of school. These cohorts were affected by the short school years just like their peers in other states. The next six cohorts, entering 10th grade between August 1969 to August 1974, graduated from March 1971 to March 1976 after a total of 10 years in school. Hence, the total schooling of these cohorts was unaffected by the short school years. Students attending Gymnasium were fully affected by the short school years. The length of their schooling was not extended for any cohorts. Obviously, the variation introduced by the Niedersachsen rules can only be exploited together with the variation across tracks and cohorts. I will use both the full interactions 
of cohort, track, and state, as well as cohort and state differences only (for states outside Niedersachsen) to identify the effect of the short school years, while controlling for main effects of each of these.

The short school year might have affected students in a variety of ways. Instructional time was obviously reduced for these students, not necessarily only during the short school years but even in later years as curricula were adapted for the affected cohorts. For example, the education minister of the state of Schleswig-Holstein decreed that the curricula for four years were to be taught during the two short school years and the subsequent two regular school years. Thus, the available time for each one year curriculum was only reduced by one sixth. In addition, some requirements were reduced for the students exposed to the short school years. ${ }^{8}$ In Baden-Württemberg, on the other hand, the curricula for the short school years were shortened, but there was no change in the requirements for the subsequent school years. However, Thiel (1973), after reading of the directives of the school bureaucracy, claims to find "no specific reductions" in the material of the core subjects like German, English and math. Additional hours of instruction were added to a minor degree.

Despite these adjustments, some students may not have been able to cope with the necessary acceleration in pace, resulting in students repeating a grade. The short school years will have lengthened the time these students actually ended up spending in school. Furthermore, students who were in primary school during the short school years may have ended up choosing a different secondary school track. I will analyze grade repetition and attendance of the highest track (Gymnasium) as outcomes directly below. These behaviors, grade repetition and track choice, will also affect the interpretation of the results on earnings. The short school year experiment does not manipulate the total amount of time spent in school directly but rather the length of the instructional period in a certain set of grades.

\footnotetext{
${ }^{8}$ For example, the state of Schleswig-Holstein usually required the reading of three authors for the Great Latin Exam (Grosses Latinum), but reduced the number to two during the 1966 short school year.
} 
Test scores on a standardized test would be the preferred choice to assess the effects on student achievement and learning. Unfortunately, there are no uniform standardized tests available in Germany. However, I will present the results of three studies undertaken at the time, which tested students in school during the short school years. I also analyze grade repetition in primary school and secondary track choice. In order to understand these outcomes, it is important to note that grades and therefore academic achievement in primary school are a major determinant of both. Unlike in the United States, whether a student repeats a grade is determined by the teacher and school largely without input from the parents. In principle, there is a set rule, and if certain grades of a student drop below a cutoff, the student is required to repeat a grade. In practice, there is some teacher discretion involved. A single teacher is typically responsible for most subjects of a class in primary school, and there is a subjective component to grades (like class participation), so that the teacher can influence promotion. Teacher discretion is larger in 1st grade and grades play less of a role than in later years. Nevertheless, grade repetition should largely reflect academic achievement, especially in grades 2 to 4 .

The same is true for the choice of the secondary school track after grade 4 . In the 1960s, all states except Berlin started Gymnasium, the highest track, with grade 5, while middle school started in many states only with grade 7. ${ }^{9}$ I therefore concentrate on the decision to enroll in Gymnasium. At the end of grade 4, the primary school will make a recommendation based on grades, possibly specific exams, and teacher assessment, whether a student should attend Gymnasium. Independent of this recommendation, parents can choose to have their child apply to Gymnasium. In case of a negative primary school recommendation, the student may have to take an admissions exam, which determines whether the Gymnasium will admit the student. Whether a student enrolls in Gymnasium therefore depends both on parental choice and on the academic performance of the student. Since low achieving

\footnotetext{
${ }^{9}$ Some states treat grades 5 and 6 as an orientation phase, and allow entry into Gymnasium in grade 5 as well as in grade 7 .
} 
students are unlikely to enter Gymnasium, track choice is a useful measure of student achievement.

After the initial choice of a secondary track is made, switching tracks, while possible in principle, is rare. For example, in 1966, before the first short school year, 13579 students switched into Gymnasium from basic or middle school, compared to 174828 students entering the first grade of Gymnasium from primary school. Thus, switchers are only about 7 percent of total accessions into Gymnasium in that year. Most of this lateral movement takes place by grade 7 .

\subsection{Measurement Framework}

In order to evaluate the effect of the short school years on various outcomes, I construct a variable $D_{i}$, indicating whether an individual participated in the short school years. These indicators are constructed based on an individual's year of birth, state, and secondary school track or graduation year as described in detail below. I then estimate equations of the form

$$
y_{i}=\alpha+\beta D_{i}+\gamma_{s}+\delta_{g}+\lambda_{c}+\theta_{a}+\phi_{t}+\mu_{f}+\varepsilon_{i}
$$

where $y_{i}$ is an outcome, like the log of earnings or wages, $\gamma_{s}$ is a set of state effects, $\delta_{g}$ is a set of secondary school track effects, $\lambda_{c}$ is a set of year of birth or cohort effects, $\theta_{a}$ is a set of age effects, $\phi_{t}$ is a set of time effects, and $\mu_{f}$ is a gender effect.

The regressor of interest, $D_{i}$, is an interaction of state, year of birth, and secondary school track effects. Because state, cohort, and secondary school track are likely to influence wages independently of the length of school, it is important to include these control variables in the regression. The implicit assumption is that $D_{i}$, conditional on state, year of birth, and secondary school track is as good as randomly assigned. The state where an individual went to school and track are variables which are (at least partly) under the control of individuals. A possible concern is that parents moved across states or decided to send their child to a different secondary school track in response to a state's decision to introduce the short school years. This is unlikely to be 
the case. The ultimate decisions of the states whether to introduce the short school years were only made at the beginning of 1966. This left little time for parents to move in order to have their children attend school in a different state. The only students possibly affected were therefore those living near the border of one of the states without the short school years (Hamburg and Bavaria, since West-Berlin has no borders with other West-German states) who could possibly send their children to a school in the neighboring state. This should be a very small proportion of students.

In a given state (outside Niedersachsen), the secondary school track only matters for the assignment of $D_{i}$ for students who were going to be in grades 10 or higher at the time of the short school years. These students made their track choice many years earlier. By grade 9 it is relatively difficult to switch tracks. Nevertheless, students affected by the short school years in primary school may have ended up attending a different secondary school track than they would have otherwise. In this case, track would be an outcome variable of the treatment, and should therefore not be included as a control in regression (1). ${ }^{10}$ I show below that the short school years did not actually have much of an impact on the choice of secondary track. If $D_{i}$ does not have a causal effect on track, it is safe to include track as a control. In order to probe this issue, I estimate equation (1) only for students who were in grades 1 to 9 during the short school years. Track is not used in the construction of $D_{i}$ for these students in states outside Niedersachsen, so that it can be omitted from the regression in this case when Niedersachsen is excluded.

One issue in controlling for track effects is how to account for the fact that the basic track was extended from 8 to 9 years in many states during the 1960s as well. Instead of using dummies for three tracks, I divide basic track students into separate groups depending on whether they graduated after eight or nine years. ${ }^{11}$ The other controls in equation (1), for age, year,

\footnotetext{
${ }^{10}$ See Angrist and Krueger (1999).

${ }^{11}$ In Niedersachsen, the first birth cohort attending 9 years of basic school is the 1946 cohort, in Nordrhein-Westfalen, Hessen, Rheinland-Pfalz, and Baden-Württemberg the 1952 cohort, in Bavaria the 1954 cohort, and in Saarland the 1948 cohort. In all other
} 
and gender, are only included to help increase the precision of the estimates.

Notice that the regressions only control for age, and not labor market experience. The students affected by the short school years will have more potential labor market experience. The estimates I present below are a combination of the education and experience effects induced by the short school years. I have made no attempt to separate the two effects. In order to do so, it would be necessary to have an independent estimate of the effect of experience. Because of the collinearity of time, age, and cohort, I do not believe that it is possible to identify the linear portion of the experience effect convincingly. However, the individuals in the samples I use are on average between 32 and 35 years old. Hence, most of the individuals will be in the relatively flat part of their experience profile already, so that the effect due to experience is likely going to be small.

The validity of the identification hinges on the assumption that interactions of state, year of birth, and track effects do not matter for the outcome variables except for the effects of the short school years. This assumption is more likely to be satisfied when fewer cohorts are used. I therefore present regressions using the cohorts born from 1943 to 1964. This includes the cohorts potentially exposed to the short school years, those born 1947 to 1960, as well as four adjacent cohorts. Nevertheless, identification could be undermined if there were other changes, which affected some cohorts in some states. While education policy certainly was rather fluid during the 1960 s, the design here is likely to be more robust than typical differencein-difference investigations of policy changes. The reason is that the short school years came into effect, and then ended, so that there are control cohorts both before and after the intervention. Other policy changes during the period tended to be permanent, and hence largely orthogonal to the short school year regressor.

states, all birth cohorts in the sample attended 9 school years. 


\subsection{External Validity}

The various possible dimensions of contrasts across states, cohorts, and tracks, as well as the possibility to construct control groups from before and after the treatment leads to a quasi-experimental design which should result in rather good internal validity of the estimates. I have argued that the possible challenges, like mobility of parents and track choice, are unlikely to be a big problem. I will argue below that shortcomings of the data, which result in some measurement error, are also unlikely to invalidate the estimates. A bigger question is whether the estimates are very informative beyond the particular experience of Germany in 1966-67, and hence the external validity of the estimates.

As with many interesting policy experiments, there is the danger that the policy engendered a response specific to the episode. Schools and teachers may have mobilized additional resources in order to cope with the added pressure of the short school years on the students. Teachers may have increased their effort. Parents may have filled gaps left by the schools. Such responses could be due to the temporary nature of the policy, and may not be forthcoming in response to a more permanent change of instructional time. If this is the case, the German short school years may not be very informative on the broader question of the impact of the length of the school year.

At this point, it is rather difficult to assemble hard evidence on exactly what happened in schools more than 35 years ago. However, I will present a few pieces of evidence on these issues. The two German studies by Meister (1972) and Thiel (1973) both carried out surveys of a small number of teachers during the short school years, asking them about the adjustments that took place and some of the consequences.

Some state education authorities added some class room hours for affected students in certain subjects, and teachers and principals may have shifted additional hours between subjects themselves. Thiel (1973) asked teachers in 2nd, 4th, and 8th grade directly whether they gave additional hours of instruction in writing and math. Out of 21 teachers, only 19 percent report 
a regular additional hour for math and 33 percent for writing. 14 percent actually report a regular hour less in writing. Slightly more than half report an additional hour in each subject occasionally. ${ }^{12}$

Since primary school classes are typically taught by a single teacher, there is also the possibility that reading, writing and math were stressed more to the detriment of other subjects, without additional hours. According to the survey by Meister (1972), 11 out of 13 primary school teachers report shifting emphasis to reading, writing and math, particularly reading and writing. In addition, 3 of the teachers mentioned cuts in music instruction. Thiel (1973) reports that 72 percent of teachers gave additional homework in math, and 62 percent in writing. 60 percent mention that they perceived parents as working more intensively with their children. On the other hand, only one out of 13 respondents in Meister's (1972) survey mentioned more parental involvement (although this answer comes from a free form question).

In addition to added instruction, teachers may have increased their effort. The most direct piece of evidence on this is data on teacher absences assembled by Thiel (1972). He surveyed 120 schools in Baden-Württemberg, and received responses from between 77 and 86 of them for the years 1964/65 to $1969 / 70$. The results are displayed in Figure 1, and are measured as the average number of school days missed by teachers during a school year. The numbers for the short school years have been scaled up by the relative reduction in school days during those years to make the numbers comparable across time. The short school years are marked by squares on the figure. Teachers are on average absent for about 8 days a year. During the first short school year, this dropped to just below 6 days (and the change is significant). During the second short school year the number of absences increased to about 8.8 days, i.e. slightly above the level before the beginning of the short school years. Absences increased still a bit further in the first year after the short school years before falling back to their normal level.

This indicates that teachers may have put in additional effort particularly

\footnotetext{
${ }^{12}$ The numbers reported in Table 3 on p. 23 of Thiel (1973) do not match exactly his reporting of the results in the text. I report the results given in the table.
} 
during the first short school year, and may have come to school even with minor illnesses that would have normally kept them at home. This additional effort was not sustainable during the second short school year. The slightly higher level of absences even after the short school years may indicate that teachers may have succumbed to additional illnesses because of the additional stress caused by the episode. However, there are other potential explanations at least for the short school year pattern of absences. The first short school year ran from April to November, and hence did not include much of the typical flu season, while the second short school year from December to July included the bulk of the flu season.

While the evidence is less than clear cut, it certainly suggests some adjustments to the short school years. The role of additional instructional time during the short school years seems to be minor, although additional hours were used in some cases. There also seems to have been a concentration of resources on the core academic subjects, to the detriment of other fields, with music being frequently mentioned. The effort of teachers, parents, and students (through additional homework) may have been higher during the short school years. But it also has to be kept in mind that the school system already was under strain during this period because of the large baby boom cohorts being educated, and because of the general expansion of the education system. Hence, it seems unlikely that the adjustments were able

to undo all or most of the effects of the short school years on students, and this seems to be borne out by some of the evidence below.

\section{The Data}

In order to study the impact of the short school years on student performance, I analyze data on grade retention and secondary track choice. The number of students repeating a grade and the total number of students enrolled in each grade are published annually by the Federal Statistical Office in the serial Fachserie A. Bevölkerung und Kultur, Reihe 10, I, Allgemeines Bildungswesen. Thus, I have the population data on grade retention avail- 
able.

I measure enrollment in the highest secondary school track (Gymnasium) from the same data source, but it is harder to get a clean measure of this. The Federal Statistical Office does not report a consistent series of students leaving fourth grade to enter Gymnasium during the required time period. Instead, I use the number of students entering 5th grade of Gymnasium in a particular school year divided by the number of fourth graders in the state during the previous year, since this is the only measure that I can construct consistently. This measure is slightly problematic, because some students may move across state borders when they change school. In addition, some entry into 5th grade of Gymnasium is from other grades than grade 4 in primary school (e.g. from later grades in basic school). Finally, some states allow entry into Gymnasium after grade 6 in addition to grade 4. In order to minimize the impact of this, I limit the analysis to states other than Berlin and Bremen, where this is a particular problem. ${ }^{13}$

Earnings data are taken from three data sets, each with its own strength and weaknesses. ${ }^{14}$ The first is the Qualification and Career Survey (QaC) collected by the Institut für Arbeitsmarkt- und Berufsforschung (IAB) and the Bundesinstitut für Berufsbildung (BIBB). This is a repeated cross section of employed workers of German nationality in the age group 15 to 65 . I use the four waves for 1979, 1985-86, 1991-92, and 1998-99 each of which samples about 25,000 workers. The large sample sizes are one of the main advantages of this data set.

The earnings variable in the surveys is gross monthly earnings. Respondents in the 1979 survey were asked to report their earnings in 13 brackets, in the 1985-86 survey in 22 brackets, in 1991-92 in 15 brackets, and 1998-

\footnotetext{
${ }^{13}$ In addition, the 1970 edition of Fachserie A. Bevölkerung und Kultur, Reihe 10, I, Allgemeines Bildungswesen did not report data which allowed me to construct a measure consistent with the other years. Therefore, data for the school years starting in 1969 or 1970 are missing for some states.

${ }^{14}$ Some other data sources could in principle be used for this analysis. For example, the German Socioeconomic Panel (GSOEP), which has tracked respondents since 1984, would allow annual observations on the same individuals for about 18 years, but does not offer any particular advantages compared to the datasets used here.
} 
99 in 18 brackets. I assign each individual earnings equal to the bracket midpoint. ${ }^{15}$ I then convert the variable to an hourly wage by dividing by the number of weekly hours. I also present results using monthly earnings directly.

The year of school entry is not available in the QaC, but it provides year of birth, the year when the individual graduated from secondary school, and the highest secondary school degree attained. This allows various ways to construct variables for the students affected by the short school years. I construct variables for the number of short school years an individual was exposed to using the interaction of cohort and track. This is done in two ways. The first is to use year of birth and the highest secondary school degree obtained. German children enter school in the year after they have reached their 6th birthday. Using this information, it is possible to determine how many short school years an individual should have been exposed to in a state with the short school years.

Table 1 displays how this assignment is done for the birth cohorts from 1946 to 1960. There are a few caveats. First, some students enter school early or late, and I do not have any information on this. Secondly, somebody born in 1960 might have entered school either in November 1966 and experienced one short school year, or in summer 1967 missing the short school years altogether. Since approximately an equal number of individuals will have had zero and one short school years, I assign everybody born in 1960 half a short school year. Because I adjust the value of the covariate appropriately, this assignment will lead to a consistent estimate of the effect of the short school years despite the measurement error introduced by not knowing the true value.

Alternatively, I construct a similar measure using the year of birth and

\footnotetext{
${ }^{15}$ Because of the large number of brackets this is unlikely to introduce much more measurement error than is done by respondents' rounding continuous amounts. The top bracket in 1979 was DM 5,000 or more which I assigned a value of DM 7,500, in 1985-86 and 1998-99 it was DM 15,000 or more which I assigned a value of DM 17,500, and in 1991-92 it was DM 8,000 or more which I assigned a value of 12,500 . Only 1.0 percent of sample observations are in the top income bracket.
} 
year of graduation. There is a similar missing information problem here. Everybody born in 1960 is again assigned half a short school year. Individuals graduating in 1966 might have also experienced either zero or one short school year, and are assigned half a short school year as well. Both measures of the short school year are scaled so that they measure the amount of instructional time missed in years, and regression coefficients in the earnings regressions are directly comparable to estimates of the returns to schooling.

The two measures of exposure to the short-school year will naturally differ. The variable based on year of graduation will count individuals as treated by the short school years if the individual was still in school in 1966/67 because of earlier grade repetition. These individuals will not be assigned short school years using the assignment based on the highest degree. If individuals repeating grades have lower earnings for reasons other than the short school year, then the measure based on highest grade will overestimate the relative earnings of those exposed, while the measure based on school leaving will underestimate these earnings. Of course, there are reasons to believe that both variables have substantial measurement error from other sources as well. There will be misreporting both of the highest degree attained and the year of graduation. To the degree that the measurement error stems from year of birth, there is nothing I can do about this. Measurement error in the other variables can be filtered out by using one of the exposure measures as an instrument for the second, as long as these measurement errors are independent.

Unfortunately, the QaC does not identify the state in which an individual grew up or attended school. Only the state of residence is available. The short school year measures constructed above are set to zero for residents of Bavaria, Hamburg, and Berlin. For residents of Niedersachsen, they are also set to zero for respondents with basic school degrees and the middle school cohorts which were unaffected. The state of residence is only a good proxy for the state an individual went to school in if individuals do not move frequently between states. I present some evidence on this below.

I also construct a measure of years in school defined as year of graduation 
minus year of birth minus 6 . This measure is fairly noisy, because I do not have detailed enough information on birthdays to know the exact date when the person first entered school, and because there is some parental discretion. Nevertheless, this variable is useful as it lets me assess whether students exposed to the short school years received less schooling. I limit the $\mathrm{QaC}$ sample to respondents for whom this length of schooling variable is in the range of 6 to 15 years, in order to minimize the effect of misreporting on the estimates.

The second data set I use is the German General Social Survey (ALLBUS) from 1980 to 2000. This is also a repeated cross section survey. It samples about 3,000 respondents of German nationality who are 18 years or older in each wave. The surveys were conducted every two years with an additional smaller survey for 1991, right after German unification. I only use the west German portion of the waves after 1990.

The only income variable in the survey is net monthly income. The questionnaire is not very explicit what types of incomes to include (e.g. whether respondents are supposed to report asset income). Income was elicited as a continuous variable. Respondents refusing to report income were asked a second question, which allows them to report their income in 22 brackets. This increases the response rate substantially. I incorporate the bracketed income information by assigning midpoints again. ${ }^{16}$ Despite the different concepts, the distribution of income looks very comparable to the distribution of earnings in the QaC data. A weekly hours variable is available from 1984 onwards but is missing for many observations. Because the sample is relatively small to begin with, I use the monthly income directly in the regressions.

The ALLBUS provides year of birth and the highest secondary school degree attained, ${ }^{17}$ which allows me to construct the first measure for the number of short school years an individual was exposed to as described above. From

\footnotetext{
${ }^{16}$ The top bracket is DM 15,000 or more to which I assign a value of DM 17,000 , the mean among respondents reporting a continuous income amount above DM 15,000.

${ }^{17}$ Starting in 1990 , there is also a variable on the total number of years of schooling. I do not use this variable because it is only available for a few waves.
} 
1982 onwards, the survey also collected month of birth. This information is useful to decide whether someone born in 1960 attended one short school year or none. I use the information where available, and assign everybody born in 1960 half a short school year in the 1980 wave or if the month of birth information is missing.

The ALLBUS identifies the state of residence in every wave. I use this in the same way as for the QaC data. In addition, the 1991, 1992, 1994, and 2000 waves also ask about the state of birth and since when an individual has lived in the current state of residence. This information lets me assess to what degree individuals have moved across state lines from the time they grew up. Table 2 displays some summary statistics about the interstate mobility of individuals. It reveals that about 80 percent of all respondents live in their state of birth. The rates differ slightly, depending on whether the calculation is based on the state of birth variable or the variable asking about the time in the current state. There is relatively little mobility between birth and age 18. Therefore, state of birth will be a better indicator than state of current residence for the state in which an individual attended school. Most relevant for the purpose of this paper, more than 80 percent of individuals at risk of participating in the short school years (the birth cohorts 1947 to 1960) have lived in their current state already in 1965. The percentage of people in their state since 1965 or earlier is even higher for current residents of Bavaria and Niedersachsen, but it is very low for residents of Hamburg and Berlin. While the latter are relatively small states, there will be some measurement error introduced by the fact that many individuals move in out of these states. If migration is unrelated to the effects of the short school years this measurement error will lead to pure attenuation.

The third data set comes from social security records. It is based on the IAB Employee Sample (IAB Beschäftigtenstichprobe), a 1 percent sample of social security records. The sample includes only records on employed individuals, and excludes civil servants, self-employed, and those in marginal employment because these groups are not covered by the general social security system. This includes about $80 \%$ of all workers. The dataset is a 
panel. Once sampled, an individual is followed as long as a social security record appears for that individual. The dataset is described in more detail in Bender and Hilzdegen (1995) and Bender, Haas, and Klose (2000).

I obtained cell level means, medians, and standard deviations of earnings, as well as characteristics of the individuals spanning the period 1975 to 1995. The sample is restricted to Germans living in the west German states. The cells are based on year, age, state, and level of schooling. The regional indicator is the state of the workplace. Every individual was assigned the state where they worked in 1975 or when they first entered the dataset.

The earnings measure provided is gross pay subject to social security contributions, and it is truncated at the social security maximum. For each cell, I know now many observations are at the maximum, and I only use cells where the fraction at the maximum is 50 percent or less. I also discard 106 cells based on a single observation. The sample used in the analysis has 8605 cells, based on 2 to 1447 observations. The mean number of observations in the cells is 206 , the median is 82 , and there are in total more than 1.7 million micro records underlying the cell statistics.

The advantage of the social security data is its large sample size. However, this is mitigated by the fact that it is a panel with repeated observations on the same individuals. Another drawback is the coarse information on education. As a result, the $\mathrm{QaC}$ is my preferred data set for this analysis, and I will present the most detailed results from that data source.

\section{Results}

\subsection{The Impact of the Short School Years on Years in School}

The first question raised by the introduction of the short school years is whether affected students did actually spend less time in school. While the nominal time reduction due to the short school years was about two thirds of a school year, students' behavior might have adjusted to undo part of this 
reduction. In the $\mathrm{QaC}$ data, I can construct a measure of the length of time a respondent spent in primary and secondary school. Regressing this variable on the short school year measure can be interpreted as the first stage of the problem. I only do this for the first measure of the short school years based on tracks because there is a mechanical correlation between the second measure based on graduation year and the length in school variable (and hence measurement error in both will drive the correlation). Conditioning on secondary school track and gender as well as a full set of year, year of birth, age, and state of residence dummies, I find that the short school years reduced time in school by 0.39 months (with a standard error of 0.05 ) for each month of time nominally lost by the short school years. The effect is far less than one, and it is quite precisely estimated.

One of the main reasons why the length of schooling variable is not picking up the full effect of the short school years is probably that the length variable can only be computed in full years, while the short school years were a fractional year treatment. I therefore would not expect these results to be very precise. Individuals, who attended the first short school year should report graduating an entire year ahead of the schedule had they just attended school years of regular length (because both the beginning and the end of the first short school year were during the same calendar year). Since most affected individuals participated in both short school years, this might actually lead to an overstatement of the effect, since the measured length of schooling would be reduced by a whole year rather than two thirds of a year. Furthermore, there were some changes in the exact dates when children became eligible to enter school when the beginning of the school year shifted. This is not reflected in the length measure.

It is worthwhile keeping in mind that the measurement of the short school year regressor is likely to be imperfect as well. Individuals presumably misreport both their year of birth and their highest level of schooling. For example, Ashenfelter and Rouse (1998) find that about 6 percent of the variance in highest grade completed is due to measurement error in a sample of twins.

In addition, some individuals will have moved between states since they 
went to school. The impact of this latter measurement error can be assessed with the aid of the ALLBUS data, which have both state of residence and state of birth. These data come from the 1991, 1992, 1994, and 2000 waves of the ALLBUS, therefore respondents are slightly older on average than in the QaC sample, so that the degree of mobility in the ALLBUS data is likely somewhat overstated. In addition, assuming that state of birth corresponds to the state of schooling ignores that some students moved between birth and the time they went to school, again overstating mobility. Nevertheless, using a measures of exposure to the short school year based both on year of birth, call it $D_{i}^{*}$, and year of residence, $D_{i}$, allows me to quantify the bias from measurement error. If the measure based on year of birth was correct, then the coefficient from a regression of $D_{i}^{*}$ on $D_{i}$ measures the attenuation from using $D_{i}$ as a regressor instead of the true measure. Including the other covariates mentioned above, this attenuation factor is 0.84 in the ALLBUS with a standard error of 0.02 . This implies that the short school years reduced schooling by $0.39 / 0.84=0.45$. While I do not want to put too much credence in the numerical estimates obtained here, it is comforting that the data show a clear and very significant impact of the short school years on the actual time in school.

\subsection{The Impact on School Performance}

The most direct method to assess school performance is to compare the results of standardized tests. There is no standardized testing system in Germany, which allows such a comparison. However, I will present the results of three studies undertaken at the time of the short school years. The authors of two of them tested the affected students themselves, while the third study relied on tests routinely given as part of the secondary track selection proce-

dure. I will also present some indirect results based on grade repetition and transition into the more academic secondary school track.

The first two studies are dissertations, and both authors administered tests themselves. One tested students in the Saarland (Meister, 1972), the 
second students in Baden-Württemberg (Thiel, 1973). Both exploit the quasi-experimental design of the short school years, and are competently executed. Nevertheless, both have a number of limitations as well. One problem is that both studies relied on existing tests, which may not be exactly appropriate for the time at which students were tested. The samples were not overly large: 435 and 449 children in 13 classrooms for the Saarland, and between 146 and 365 students in 5 to 10 classrooms in Baden-Württemberg.

The third study was conducted in the city of Frankfurt in the state of Hessen (Schlevoigt, Hebbel and Richtberg, 1968) and relied on tests routinely given to 4th graders there. The tests were specific to the grade level, and similar in format to regular tests during the school year. The samples were much larger, covering between 1148 and 3124 students (with the exception of one subtest, where only 291 students were tested after the short school years). The treatment groups were tested in 1968, i.e. one year after the end of the short school years, so that they were in 2nd and 3rd grade during the short school years. The control groups were tested in 1963 or 1965. One drawback of the study is that the only publication is a terse, two page article in a journal for teachers. The results of the studies are summarized in Table 3. Results were the students in the treatment group performed better are shaded in grey.

The study by Meister (1972) for the Saarland focused on teaching methods in the early primary grades, and hence he only tested 2 nd graders. The tests for the treatment group were performed after the end of the second short school year, i.e. after the tested students had been exposed to two short school years. The control group consisted of students in the same schools who started school in summer 1967, i.e. after the short school years were over. They were tested after a period that was equivalent to the short school years, i.e. during the middle of their second school year. The author chose this timing because he was interested in a control group of the same age as the treatment group. The design therefore is trying to establish whether learning was faster during the short school years but not whether the same amount of material could be learned by the end of the school year. The re- 
sults in the first panel of Table 3 show that the treated students consistently performed much better than the control group.

One problem with the design is that the tests used may have been most appropriate for the end of the second school year. The students exposed to the short school year should therefore have covered all the required material, while some of the tested material might not have been as easy for the control group. ${ }^{18}$ Another problem is the possibility of knock-on effects of the short school years: if teachers expanded more effort during the short school years, they could have been doing a worse job in the subsequent years, so that teaching quality for the control group was worse.

The second study by Thiel (1973) for Baden-Württemberg addresses more directly the question I am interested in here, namely whether the affected students learned the same amount as students in regular school years. He tested 2nd, 4th and 8th graders. The treatment group was tested twice, first at the end of the second short-school year, and the second time at the end of a period equivalent to two regular school years. The treated students will generally have been in the following grade during this retest, and they were given parallel forms of the same test at the two testing dates. The control groups used in this study are generally samples of tested students used to norm the tests, i.e. these tests will have been performed prior to the short school years in all the states of West Germany. The problem with this comparison is that the curriculum may be different in other states, and the test may therefore be more appropriate for the treatment or the control group. Some of the control tests also date back various years, and standards in schools may have changed over time. In some cases, the control group results were collected by the author or his colleagues in Bavaria (with no short school years) or in Baden-Württemberg after the short school years (as in the case of the Saarland study).

The second panel in Table 3 shows that the results for the second graders

\footnotetext{
${ }^{18}$ Thiel (1973), who uses the same test describes it as designed to test knowledge at the end of the 2nd grade. On the other hand, he goes on to say that the test is too easy for the 2nd graders in Baden-Württemberg at that stage.
} 
generally confirm the findings of the Saarland study: treated students performed better after spending two full school years in school (the regularregular comparison). Nevertheless, they did not reach the control group standards at the end of the short school years (the regular-short comparison), although the writing difference is not significant. Thiel (1973) discounts the results for the writing test somewhat because he believes that it is too easy for the 2nd graders in Baden-Württemberg.

The results for 4th graders (third panel in Table 3) generally shows the treated students at par with the control group at the end of the short school year (the regular-short comparison) and at par or outperforming the control group after a similar time in school (the regular-regular comparison). The exceptions are the reading, vocabulary, and mental arithmetic subtests. Thiel (1973) attributes the reading and vocabulary results to the fact that learning in these skill categories may be more influenced by maturation and hence age (because a lot of reading takes place outside school) rather than training. Since the treated students are about eight months younger at the end of the short school year than the control group students, this difference may explain the results. The test for mental arithmetic contained in a number of questions on fractions, a subject not covered in Baden-Württemberg until grade 5. This would explain the lower performance of the treatment group compared to the national control after the short school years, and the catching up when the same students were retested during the 5th grade.

Thiel (1973) also tested one group of 4th graders in 1969. This group would have been affected by the short school years during the first two grades. Except in reading and vocabulary the results for this group are at par with the control group. Even though he found deficiencies for the 2nd graders in writing and math right after the short school years, the children seemed to have made up these deficiencies within the next two years. The students are again weaker than the control group in reading and vocabulary, which may again be attributable to their lower age. On the other hand, the results for this group do not bear out Thiel's interpretation for the mental arithmetic test. The 4th graders who were affected by the short school years earlier 
were able to perform as well as the norm despite the fact that they would not have been instructed in calculations involving fractions.

Schlevoigt et al. (1968) does not report means of the scores on the tests or t-statistics, but only tabulates the distribution. I have therefore calculated the fraction of students scoring at some level around the median on each test. I have also constructed t-statistics based on the counts given in the paper. These will be somewhat inexact because of rounding in the publication. They will also overstate the true significance levels, because they do not take into account the sampling at the class room and school level.

The results in the Schlevoigt et al. (1968) study fall somewhere between the regular-short comparison and the two years later comparisons in Thiel (1973), since the treated students in Frankfurt experienced the short school years in grades 2 and 3 . The results differ markedly from those obtained by Thiel. In all tests, the treated students performed worse, although the difference is only large and clearly significant in writing. Curiously, writing is the subject where the students tested by Thiel actually did slightly better after the short school years.

Finally, students affected by the short school year in 8th grade generally performed as well as the control group in the Thiel (1973) study. However, the testing instrument may have been weak for that group. The writing test only tested spelling but not punctuation, and hence focused on skills generally acquired earlier. Similarly, the math test contained numerous questions on material of the earlier grades.

In summary, these studies show that the affected students may have had some deficiencies at the end of the short school years in the core subjects of reading, writing, and math, although these subjects presumably received the most attention at the time. ${ }^{19}$ On the other hand, the students were always

\footnotetext{
${ }^{19}$ Thiel (1973) also presents results from a small survey of teachers, informally assessing the knowledge of the students at the end of the short school years. He distinguishes the teachers who taught the students during the short school years, and those who taught them in the subsequent year. In both cases, 62 percent of the respondents thought that the affected students learned the required material fully, while 38 percent saw deficiencies. The teachers saw the most problems outside the core subjects.
} 
on par and typically ahead of their peers when tested at the same age. The results also reveal that any immediate effects on learning seem to have been eradicated when students were tested two years later. This indicates that the eventual effects of the short school years on learning of the affected cohorts should be small at best.

In order to corroborate these findings, I present some results on grade repetition and on the fraction of students going on to Gymnasium, the highest secondary school track, after grade 4. Data on grade retention of affected and unaffected grades in primary school are presented in Table 4. States are grouped into one of three groups: seven states with the short-school year, Bavaria with the regular school year, and Berlin and Hamburg with the long school year. I exclude Niedersachsen from this table because of its special provisions for graduation, which makes it unclear whether students attending primary grades should have actually been affected by the short school years. Berlin and Hamburg are control states, because schools should have adapted the curriculum to the long school year, since students would eventually graduate after the normal length of total schooling. Retention rates are presented for the school year 1965-66, the last year before the transition, the 2nd short school year (1966-67) and the following four regular school years. During those years, older grades will have been affected by the transition, but not new grades entering since 1967. This allows a variety of contrasts.

Looking at first grade, it is apparent that retention rates did not fluctuate much over the period in either the states with the short school year or the control states. Things look different for 2 nd grade. In both years when 2 nd grades are affected, grade repetition jumps by about 1 percentage point in the short school year states, and remains rather steady in Bavaria and the long school year states. Similar effects are visible for grades 3 and 4 . Grade repetition drifts up by about 1 percentage point in the two years after the short school years and then drops back by about the same amount for the unaffected grades entering school after the short school years. The effects of the short school years on grade repetition often seem to be long lived, and are visible even a few years after the short school years. This may be due to 
the fact that material had to be taught more quickly during the school years immediately after 1966 as well. The contrast with Bavaria for grades 2 to 4 are also displayed in Figures 2 to 4 .

Data on the fraction of students entering Gymnasium are presented in Table 5. These data are presented for the cohorts entering 5th grade from 1964 to 1971 . The three years from 1964 to the beginning of the 1st short school year in 1966 are pre-treatment years, since students completing fourth grade at that time were unaffected by the short school years. The next transition is presented for 1967, the first regular school year after the short school years. Students starting grade 5 during the years 1967 to 1969 will have been exposed to both short school years in the treatment states. 1971 represents a post treatment year. ${ }^{20}$ The treatment states are being compared to Bavaria and Hamburg, since the data on Berlin are not comparable. Results for Niedersachsen are also presented in the table but it is again unclear whether Niedersachsen should be a treatment or control state.

A notable feature of Table 5 is that the fraction of students attending Gymnasium increased over this period. Furthermore, the upward trends seem to differ across states. They are much more moderate in the treatment states and Bavaria then in Hamburg. The strong rise of Gymnasium enrollment in Hamburg may stem from the fact that these results are calculated from the number of students entering Gymnasium in a state. For example, some of the students starting Gymnasium in Hamburg might have come from primary schools from outside the state (which is basically a city) as more and more suburban parents sent their children to attend city schools during this period when Gymnasium enrollments expanded. Gymnasium enrollment in Niedersachsen is slightly below trend during the treatment years. Therefore, it matters exactly how this state is treated in assessing the impact of the short school years.

Table 6 presents regression results for the effects of the short school years on grade repetition and entering Gymnasium. Controlling for grade, year, and state effects, I find sizeable effects of the short school year on grade

\footnotetext{
${ }^{20}$ Data for 1970 are not available for all states.
} 
retention. Retention rates have increased by about 0.8 to 0.9 percentage points due to the short school years and the estimates are highly statistically significant. The effects are also large in magnitude, since only 2 to 5 percent of students repeat grades every year. The results do not depend very much on whether Niedersachsen is treated as a treatment or control state or dropped from the sample altogether. Column (2) shows that the results are changed little when state*grade interaction effects are controlled for. Column (3) presents results that are limited to grades 2 to 4 , where grade repetition is most likely to reflect academic achievement. The results are again very similar.

The last column in Table 6 presents the results for entering Gymnasium. As was obvious from Table 5, here the treatment of Niedersachsen matters more. When Niedersachsen is treated as a treatment state, the effects on track choice are zero. On the hand, the data suggest that more students exposed to the short school years attended Gymnasium when Niedersachsen is treated as a control state. However, in neither case do the data suggest that reducing the length of school during primary grades led to fewer students attending Gymnasium.

The grade repetition and secondary school transition results therefore give a picture that complements the earlier discussion of the testing results. The grade repetition results indicate that predominantly weaker students may have been hurt by the reduction in the length of the school year, maybe because these students need more repetition to effectively grasp the material being taught. ${ }^{21}$ Students further up in the ability distribution do not seem to have been adversely affected by the short school years, as evidenced by the results on Gymnasium entry. At the time, about 80 percent of students did not enter Gymnasium after grade 4, so that these results speak on impacts fairly high up in the ability distribution.

How much of the reduction in the length of schooling will be undone by

\footnotetext{
${ }^{21}$ This actually contrasts with the findings of Meister (1972), who looks at percentile comparisons across the distribution of test results. He does not find any evidence that weaker students performed worse during the short school years. The same is true in the results presented in Schlevoigt et al. (1968).
} 
the fact that reducing term length will cause some students to repeat grades? Students on average stayed in school for 10.1 years. Someone affected by the short school years will have on average 5 more years of schooling after the short school years. Taking an impact of 0.009 on grade repetition as representative, and assuming that this effect persists for affected students for each year after primary school, implies that grade repetition added about 0.05 of a school year to the average time students spent in school, which is not very large compared to the initial reduction of two thirds of a school year.

\subsection{The Impact on Earnings}

Table 7 presents regressions of log wages and earnings on the short school year indicators using the $\mathrm{QaC}$ data. The regressions control for the maximal set of year, age, and year of birth dummies, secondary school track, state of residence, and gender. This means that identification is achieved by using both the second and third level interactions implied by the short school year measures. The regressions use the cohorts potentially affected by the short school years (1947 to 1960) as well as four adjacent birth cohorts (i.e. the sample consists of the cohorts 1943 to 1964). The absence of second or third level interactions of year of birth, state, and track, apart from effects due to the short school years, should be most plausible in this relatively narrow sample. Different sources of identification are explored below. The top panel in the table reports coefficients using log hourly wages as the dependent variable, while the bottom panel reports similar regressions using log monthly earnings.

The short school year measures are scaled so that they correspond to the fraction of a calendar year lost because of the reform. The coefficients on the short school year measures can therefore be interpreted analogously to a return to a year of school. The results for the measure based on tracks in column (1) are basically zero and they are relatively precisely estimated. The 95 percent confidence interval for the effect of reducing time in school by 
a year ranges from -0.03 to 0.02 . Taking a return to schooling of 7.5 percent as the benchmark, the estimates in column (1) suggest that the negative effect of the short school years was at most 40 percent as large. These results indicate that the short school years did not seem to have any detrimental effect on the earnings of affected students, and large effects can be ruled out. $^{22}$

Using the second measure of the short school years based on graduation year in column (2) yields very similar results. Coefficients are slightly positive when the second measure is used as an instrument for the first, as is shown in column (3). This indicates that measurement error may bias the results in column (1) towards zero, but the true coefficient is positive, rather than negative. Column (4) shows regressions which are limited to men for whom selective labor force participation should not be much of an issue. The effects are again slightly positive.

Table 8 probes the specification further by changing the exact set of treatment and control cohorts included in the sample. Column (1) only uses cohorts in primary school during the short school years, and column (2) uses those affected in grades 1 to 9. These specifications also include the adjacent unaffected cohorts born from 1943-46 and 1961-64 again. The coefficient estimates change little from the previous table, and there is no particular pattern to the results for earnings and wages, suggesting that any differences are likely due to sampling variation.

The identification in these specifications only relies on the interaction of state and year of birth but not secondary school track, since everybody in grades 1 to 9 in a treatment state was affected by the short school years. The only exception to that rule is the state of Niedersachsen. Column (3) therefore uses the same sample as column (2) without Niedersachsen. It is

\footnotetext{
${ }^{22}$ In principle, one should assess the effect of the short school years on the present value of life-time earnings, rather than earnings in just one year. Since the short school years increased grade repetition and grade repetition involves the loss of a year in the labor market, this effect will not be captured by the results. However, this effect will be trivial because working lives are relatively long and the effects on grade repetition were modest in the aggregate.
} 
then possible to omit the controls for secondary school track. The results are again positive, indicating that controlling for track does not bias the results upwards. ${ }^{23}$ This is not surprising, since the short school years did not seem to affect track choice very much in Table 6 .

Column (4) includes only secondary school students, but omits primary school students from the sample. The differences are small when comparing the results to the primary school sample in column (1). This indicates that the absence of effects of the short school year is not particular to reducing term length in either primary or secondary school. It is interesting to take this even one step further, and assess how the impact of the short school years differ depending on the grade when a student was affected. For example, it might be that there was a detrimental effect only for students in higher grades, because these students had little time to catch up with missed material before graduation. Figure 5 plots the coefficients of this exercise together with a 95 percent confidence band. The grade by grade estimates are less precise, and the width of the confidence interval is about 10 percent and wider for low and high grades. Nevertheless, the plot reveals no particular pattern of the coefficients by the grade level when students were affected.

The results from the ALLBUS, shown in Table 9, indicate a slightly negative impact of the short school years. The point estimate in column (1) is -0.018, implying almost a 2 percent loss in earnings for each year less in school. Unfortunately, the ALLBUS samples are much smaller, leading to a relatively imprecise and insignificant estimate. This is true even more in column (2), where the sample is restricted to the four waves from 1991, 1992, 1994, and 2000. The basic story changes little in this subsample. Since these waves of the ALLBUS data identify state of birth, they allow a coding of the short school year measure which should be more accurate than the measure based on state of residence. In fact, a comparison of results using the two measures in columns (3) and (4), including state of birth effects,

\footnotetext{
${ }^{23}$ The coefficients in column (3) are also more positive when compared to a regression that excludes the Niedersachsen observations and includes track dummies, which is the relevant comparison here.
} 
reveals that measurement error may play some role, but the coefficient based on the measure using state of birth in column (4) is again more positive. This finding also suggests that it is unlikely that the true coefficient is negative, and the finding of a small effect is simply due to attenuation from mobility across states. But the precision of the results does not allow any strong conclusions.

Finally, I estimated the same model on the social security data. Recall that the social security earnings are truncated at the taxable maximum. In order to deal with the truncation and the grouped nature of the data, I used median regression in this case. I follow Chamberlain's (1994) suggestion to estimate a regression on the cell medians which are not subject to truncation, using the cell sizes as weights. This estimator can be interpreted as a minimum distance estimator. It is similar to Powell's (1984) censored least absolute deviations estimator for the underlying micro data. The calculation of the standard errors, which account for the serial correlation introduced by the panel character of the data, is described in the appendix.

The estimate of the short school year effect is 0.019 with a standard error of 0.020. Unlike the baseline estimates from the QaC or the ALLBUS, this estimate is slightly positive but it is also not significantly different from zero. The most useful way to look at the estimates together, is to combine them into a single meta-estimate. The mean of the estimates, weighted by the inverse of their sampling variances, is 0.003. Assuming that the samples are drawn from the same population, and that the estimates reflect the same parameter, the sampling variance of the meta-estimate, $v_{m}$, is given by

$$
\frac{1}{v_{m}}=\left(\frac{1}{v_{1}}+\frac{1}{v_{2}}+\frac{1}{v_{3}}\right) .
$$

This yields a standard error of 0.011 . Overall, the results from the three data sets do not indicate any negative effects of the short school years on earnings. The combined estimate is precise enough to rule out any sizeable negative effects: the 95 percent confidence interval ranges from -0.019 to 0.026. Various checks on the specification and potential biases from measurement error all indicate that this is not because the estimates are biased up, at least not too 
any significant degree. Hence, this is fairly strong evidence that a moderate reduction of term length in Germany did not have adverse effects on earnings.

\subsection{The Impact on Civic Outcomes}

My findings so far indicate that the short school years had little impact on the learning of key labor market relevant skills and on later earnings. Nevertheless, this result may have come about because educators shifted resources away from subjects like music, arts, and physical education to the core academic subjects. In addition, schools may have had less time to spend on activities like civic education. Economists have recently become rather interested in these aspects of education. There have been a number of recent studies investigating the impact of schooling on health, crime, and voting behavior. ${ }^{24}$

Following some of this work, I use the ALLBUS data to look at these issues. The dataset contains various questions on political participation and voting behavior. I use these to create a variety of measures of political disinterest, and I run regressions similar to the ones in Table 9. Table 10 displays the results. Every survey asked respondents which party they would vote for if there was a national election next Sunday. Because participation in general elections is typically high, and respondents may not want to admit to not voting, only 6.1 percent of the sample indicate that they would not vote. However, being affected by the short school year does not alter that fraction.

Slightly more respondents, 9.8 percent, say that they did not actually vote in the last national election. However, this question was not asked in 1980 and 1982, 1994, and 2000, resulting in a slightly smaller sample. Those affected by the short school years are slightly more likely to respond that they did not vote but the difference is not significant. Another question asks respondents to assess their political interest on a five point scale (missing in

\footnotetext{
${ }^{24}$ See Lleras-Muney (2002) and Currie and Moretti (2002) on health, Lochner and Moretti (2001) on crime, and Dee (2003) and Milligan, Moretti, and Oreopoulos (2003) on voting.
} 
1988 and 2000). 23 percent of respondents show little or no political interest (the two lowest categories). Political interest is higher among those affected by the short school year by 2 percentage points, and the result is again not significant. Using these three different measures, my results are clustered around zero, and show no systematic impact of the short school years.

Apart from political participation, I would like to evaluate whether individuals affected by the short school yeas are more likely to sympathize with more radical parties. The voting questions are not very helpful in this regard, because the fraction of the vote going to extreme parties is tiny. However, in 1980, 1984, and 1994, the survey also asked respondents to assess how much they liked various parties. I classify the NPD and Republikaner as extreme parties on the right, and the DKP and PDS as extreme parties on the left. The answers are given on an eleven point scale, so that five points are associated with a positive attitude, five with a negative attitude and one with a neutral attitude. I consider any of the five positive answers for one of the extreme parties as favoring this party to some degree. The mean of this variable is 5.8 percent, and the impact of the short school years is very large with 4.4 percentage points in comparison. The coefficient is marginally significant with a p-value of 12 percent.

Many of the reports by teachers have singled out music as one of the subjects that was frequently subject to reduced hours or attention during the short school years. In order to test whether this might be the case, and whether it could have an effect on later behavior, I exploit the fact that Germany has an important culture of participation in clubs. All surveys except the 2000 one asked about club membership. I aggregate all the answers for participation in a choir, orchestra, or other music related club or group. 3.6 percent of respondents are members of such a club, and exposure to the short school years reduces membership by 1.8 percentage points, with a p-value of 15 percent.

These last two results indicate that the short school years may have had an effect on civic attitudes and participation in music or the arts. While the point estimates are large, the results in the small ALLBUS samples are 
only marginally significant at best, so that it is not possible to draw strong conclusions. Nevertheless, these results indicate that the short school years may have had some cost in terms of civic education and appreciation for the arts.

\section{Conclusion}

This paper presents estimates from a reform in the West-German school system which manipulated the length of schooling for affected students without affecting the highest grade completed or secondary school degree obtained directly. The results of this paper therefore speak directly to the impact of changes in term length or other changes in the length of schooling which are independent of the highest grade completed, and the curriculum studied. The results suggest that some of the reduction in instructional time is being undone by students, for example through grade repetition. Apart from increased grade repetition, I do not find negative effects of shorter schooling. The literature on learning outcomes also did not show any consistent and permanent negative effects of the reduced instructional time. Neither the secondary school track attended nor later earnings seem to have been affected adversely by the short school years.

To what degree do these findings generalize to other settings? One reason for the minor effect of the short school years could be that there were many compensatory measures at work, including some which might have been special to this particular reform. For example, teachers and students could have worked harder during the time when school years were shortened because of the special circumstances. I have no direct evidence whether this was the case but I doubt that it explains the results. The grade repetition results seem to indicate quite clearly that some students were affected by the loss in instructional time. Furthermore, anecdotal evidence suggests that school resources were already under great strain in the mid-1960s because of the effects of the baby boom. This suggests that there were not a lot of reserves to draw on to provide higher quality instruction during this period. 
A further problem is that German wages are highly regulated by union wage setting, and the wage schedules may not have adapted to the specifics of the short school years. Nevertheless, wages may adapt if such changes are made a permanent feature of the educational system. However, German wages do seem to be flexible enough that the impact of other differences in education can easily be discerned. The returns to schooling in Germany are very close to linear and of a similar magnitude as is the case in other countries.

Of course, the short school years are not exactly the same as a reduction in term length. The German episode lead to compression in instructional time for a given curriculum for a short period, probably about two to four years. A reduction in term length, which corresponded to a similar reduction over the student's time in school, would only amount to about two weeks less per year. However, if there are few discernible effects of the short school years, a more spread out reduction in term length is unlikely to have larger effects. The German results may also not carry over to other countries because Germany has one of the longest school years in the developed world. On the other hand, German school days are short, and total instructional time per year in Germany is actually below the OECD average.

The findings are not encouraging for policy makers who wish to use lengthening the school year as a measure to boost the performance of their students, and this is more or less consistent with the previous literature. The enthusiasm of the authors of a "Nation at Risk" for longer school years may therefore have been misplaced. While 52 percent of Americans advocate that children spend more time in school, there has been little change in the length of school terms during the last two decades. Interestingly, the 1994 study "Prisoners of Time," while putting time in school at the center of their agenda, move somewhat away from simply adding instructional time to the use of that time for core academic activities. This may well be the correct conclusion, and this paper has little to say on the issue of how time in school is used.

There has been a discussion in west Germany after unification about 
reducing the time to reach the university entrance qualification Abitur (obtained at the end of the Gymnasium track) from 13 to 12 years. One reason for this proposal is the fact that the East German school system only required 12 years for the same degree. Apart from possible cost savings, it has also been seen as a useful device to reduce the age at which university graduates enter the job market. Critics object to these proposals on the grounds that educational quality might be compromised. Only one of the west German states has reduced the number of grades in Gymnasium so far (Saarland, although experiments are running in various other states), while three of the eastern states require 13 years for an Abitur now. The short school year experience suggests that it might be possible to eliminate the last year of Gymnasium without much adverse effects on the labor market performance of the students.

One caveat that has to be kept in mind is that there are some students who were hurt by the short school years: those who ended up repeating a grade as a result of the reform, and this result is also mirrored by Lee and Barro (2001) in their cross country evidence. The most poorly performing students may not be able to keep up with an increased pace implied by a shorter school year. This indicates that the length of instructional time matters differently for different students. Of course, grade repetition seems a rather inefficient mechanism to overcome the problems of poorly performing students. The move of school districts in the United States towards introducing mandatory summer school for poorly performing students seems to be a more adequate response. Another cost of shorter instructional time may be a shift away from civic education, but more study of this issue is certainly necessary before any firm conclusions can be drawn. 


\section{Appendix: Estimation of the Standard Er- rors for the Social Security Data}

The structure of the social security data is similar to the problem posed in Chamberlain (1994). I fit a weighted linear regression through the cell medians using the cell size as the weight, i.e. I estimate

$$
\hat{\beta}=\arg \min (m-X \beta)^{\prime} W(m-X \beta)
$$

where $m$ is the vector of cell medians, $X$ is the matrix of regressors, and $W$ is a diagonal matrix with elements $w_{j}=n_{j} / n$ on the diagonal, where $n_{j}$ is the size of cell $j$. This can be thought of as a minimum distance estimator. Hence the covariance matrix would have the form

$$
\Lambda_{1}=\frac{1}{n}\left(X^{\prime} W X\right)^{-1} X^{\prime} W \Omega W X\left(X^{\prime} W X\right)^{-1}
$$

where $\Omega$ is a diagonal matrix with the sampling variance of the cell median on the diagonal.

The sampling variance of the median involves the density of the data. I assume that earnings are distributed log normally in each cell. If the earnings data are truncated, I calculate the standard deviation of the uncensored distribution $\sigma_{j}$ using the estimate of the median, the censoring point $c_{j}$, the fraction at the maximum $p_{j}$, and the normality assumption using

$$
\sigma_{j}=\frac{c_{j}-m_{j}}{\Phi^{-1}\left(1-p_{j}\right)}
$$

where $\Phi(\cdot)$ is the cumulative standard normal distribution function. Given the uncensored standard deviation, the $j$-th element of $\Omega$ is calculated as

$$
\omega_{j}=\frac{\sigma_{j}^{2}}{4 w_{j} \phi(0)^{2}}
$$

where $\phi(\cdot)$ is the standard normal density function.

Chamberlain also suggests an adjustment to the covariance matrix to allow for the fact that the model estimated in eq. (2) does not fit the data 
exactly (e.g. the medians do not line up linearly). In this case, the estimates can be thought of as a linear approximation. Define $r=m-X \beta$ as the vector of approximation errors. In this case the covariance matrix will be equal to $\Lambda_{1}+\Lambda_{2}$ where

$$
\Lambda_{2}=\frac{1}{J}\left(X^{\prime} W X\right)^{-1} X^{\prime} W \operatorname{diag}\left(w_{1}^{-1} r_{1}^{2}, w_{2}^{-1} r_{2}^{2}, \ldots, w_{J}^{-1} r_{J}^{2}\right) W X\left(X^{\prime} W X\right)^{-1}
$$

and $J$ is the number cells.

A further complication arises from the fact that the cell level medians are calculated from a panel, so the same individuals will recur in different cells. The median estimates within a cohort will therefore be correlated. In order to allow for this serial correlation, I need an estimate of the covariance matrix of earnings. I have up to 21 years of data for some cohorts, and I am not aware of any such estimate for Germany (or any other country) for such a long time span. Hence, I use the results reported in Card (1994) for the United States. Card estimates a parametric model for the earnings process on eight years of data from the PSID. Using this model, I calculate the first 20 implied autocorrelations. Biewen (2002) presents estimates for German household level income. The autocorrelations reported by Biewen are about 20 to 30 percent lower than those calculated from Card's model.

Let $S$ denote the resulting autocorrelation matrix, and $S_{k}$ the submatrix for the $k$-th cohort (which may have less than 21 observations in the data). The middle part of $\Lambda_{1}$ in eq. (3) can therefore be written

$$
\begin{aligned}
X^{\prime} W \Omega^{\prime} W X= & X_{1}^{\prime} W_{1} \Omega_{1}^{1 / 2} S_{1} \Omega_{1}^{1 / 2} W_{1} X_{1}+X_{2}^{\prime} W_{2} \Omega_{2}^{1 / 2} S_{2} \Omega_{2}^{1 / 2} W_{2} X_{2}+ \\
& \ldots+X_{K}^{\prime} W_{K} \Omega_{K}^{1 / 2} S_{K} \Omega_{K}^{1 / 2} W_{K} X_{K}
\end{aligned}
$$

where the subscripts now refer to one of $K$ cohorts rather than cells. An analogous adjustment is made for $\Lambda_{2}$.

This autocorrelation adjustment is likely to overstate the degree of serial correlation. While individuals occur repeatedly in the data, some individuals enter and leave the dataset. The correlation of the cell statistics over time 
should therefore be lower than the correlation of the individual level data. Hence, the standard errors estimated in this way are likely to be rather conservative. An alternative way to estimate standard errors is by using Stata's aweights (to allow for the cell level data) and cluster by cohort (to allow for a non-parametric estimate of the serial correlation structure). The Stata standard error on the short school year variable is 0.013 compared to 0.020 calculated with the procedure described above. 


\section{References}

[1] Acemoglu, Daron and Jörn-Steffen Pischke (1999) "Beyond Becker: Training in Imperfect Labor Markets," Economic Journal Features 109, F112-142.

[2] Angrist, Joshua and Alan Krueger (1999) "Empirical Strategies in Labor Economics," in Orley Ashenfelter and David Card (eds.) Handbook of Labor Economics, vol. 3A, 1277-1366.

[3] Ashenfelter, Orley and Cecilia Rouse (1998) "Income, Schooling, and Ability: Evidence from a New Sample of Identical Twins," Quarterly Journal of Economics 113, 253-284.

[4] Bender Stefan, Anette Haas and Christoph Klose (2000) "IAB Employment Subsample 1975-1995 Opportunities for Analysis Provided by the Anonymised Subsample." IZA Discussion Paper No. 117.

[5] Bender, Stefan and Jürgen Hilzdegen (1995) "Die IABBeschaftigtenstichprobe als Scientific Use File," Mitteilungen aus der Arbeitsmarkt und Berufsforschung 28, 76-95.

[6] Betts, Julian R. and Eric Johnson (1998) "A Test of Diminishing Returns to School Spending," mimeographed, University of California San Diego.

[7] Biewen, Martin (2002) "The Covariance Structure of East and West German Incomes and its Implications for the Persistence of Poverty and Inequality." IZA Discussion Paper No. 459.

[8] Card, David (1999) "The Causal Effect of Education on Earnings," in Orley Ashenfelter and David Card (eds.) Handbook of Labor Economics, vol. 3A, 1801-1863. 
[9] Card, David (1994) "Intertemporal Labor Supply: An Assessment," in Christopher Sims (ed.), Advances in Econometrics, Sixth World Congress. New York: Cambridge University Press.

[10] Card, David and Alan Krueger (1992) "Does School Quality Matter? Returns to Education and the Characteristics of Public Schools in the United States," Journal of Political Economy 100, 1-40.

[11] Chamberlain, Gary (1994) "Quantile Regression, Censoring and the Structure of Wages," in Christopher Sims (ed.), Advances in Econometrics, 6th World Congress vol. 1, New York: Cambridge University Press.

[12] Currie, Janet and Enrico Moretti (2002) "Mother's Education and the Intergenerational Transmission of Human Capital: Evidence from College Openings and Longitudinal Data." NBER Working Paper No. 9360.

[13] Dee, Thomas (2003) "Are There Civic Returns to Education?" NBER Working Paper No. 9588.

[14] Eide, Erik and Mark H. Showalter (1998) "The Effect of School Quality on Student Performance: A Quantile Regression Approach", Economics Letters 58, 345-350.

[15] Grogger, Jeff (1996) "Does School Quality Explain the Recent Black/White Wage Trend?" Journal of Labor Economics 14, 231-253.

[16] Heckman, James, Anne Lane-Farrar, and Petra Todd (1986) "Does Measured School Quality Really Matter? An Examination of the Earnings Quality Relationship," in Gary Burtless (ed.) Does Money Matter? The Effect of School Resources on Student Achievement and Adult Success. Washington, DC: Brookings Institution Press, 192-289.

[17] Lang, Kevin and David Kropp (1986) "Human Capital versus Sorting: The Effects of Compulsory Attendance Laws," Quarterly Journal of Economics 101, 609-624. 
[18] Lee, Jong-Wha and Robert Barro (2001) "School Quality in a CrossSection of Countries," Economica 68, 465-488.

[19] Lleras-Muney, Adriana (2002) "The Relationship Between Education and Adult Mortality in the United States," NBER Working Paper No. 8986 .

[20] Lochner, Lance and Enrico Moretti (2001) "The Effect of Education on Crime: Evidence from Prison Inmates, Arrests, and Self-Reports." NBER Working Paper No. 8605.

[21] Meister, Hans (1972) Zur Unangemessenheit des Anfangsunterrichts in der Grundschule. Vergleichende Untersuchung des Einflusses der Kurzschuljahre auf Schulleistungen. Dissertation, Universität des Saarlandes.

[22] Milligan, Kevin, Enrico Moretti, and Philip Oreopoulos (2003) "Does Education Improve Citizenship? Evidence from the U.S. and the U.K." NBER Working Paper No. 9584.

[23] NCES (2000) Digest of Education Statistics 1999. http://nces.ed.gov/pubs2000/2000031.pdf

[24] Powell, James (1984) "Least Absolute Deviations Estimation for the Censored Regression Model," Journal of Econometrics 25, 303-325.

[25] Rizzuto, Ronald and Paul Wachtel (1980) "Further Evidence on the Returns to School Quality," Journal of Human Resources 15, 240-254.

[26] Schlevoigt, G., G. Hebbel and W. Richtberg (1968) "Soll und Haben nach zwei Kurzschuljahren," Hessische Lehrerzeitung 21, 183-184.

[27] Statistisches Bundesamt (various years) Fachserie A. Bevölkerung und Kultur, Reihe 10, I, Allgemeines Bildungswesen. Stuttgart: Kohlhammer Verlag. 
[28] Thiel, Bertold (1973) Die Auswirkung Verkürzter Unterrichtszeit auf die Schulleistung. Untersuchung zur Problematik der Kurzschuljahre. Dissertation, Eberhard-Karls-Universität Tübingen.

[29] Wößmann, Ludger (2003) "Schooling Resources, Educational Institutions and Student Performance: the International Evidence," Oxford Bulletin of Economics and Statistics 65, 117-170. 


\section{Table 1}

\section{Numbers of Short School Years by Birth Cohort and Secondary School Track}

\begin{tabular}{|c|c|c|c|c|c|c|c|c|}
\hline \multirow{3}{*}{$\begin{array}{l}\text { Year } \\
\text { of } \\
\text { Birth }\end{array}$} & \multirow{3}{*}{$\begin{array}{c}\text { Quarter } \\
\text { of } \\
\text { Birth }\end{array}$} & \multirow{3}{*}{$\begin{array}{c}\text { Year of } \\
\text { School } \\
\text { Entry }\end{array}$} & \multicolumn{3}{|c|}{ Year of Graduation from } & \multicolumn{3}{|c|}{ Number of Short School Years } \\
\hline & & & Basic & Middle & Gymnasium & Basic & Middle & Gymnasium \\
\hline & & & School & School & & School & School & \\
\hline 46 & all & 53 & 62 & 63 & 66 & 0 & 0 & 0 \\
\hline 47 & all & 54 & 63 & 64 & 66/Dec & 0 & 0 & 1 \\
\hline 48 & all & 55 & 64 & 65 & 67 & 0 & 0 & 2 \\
\hline 49 & all & 56 & 65 & 66 & 68 & 0 & 0 & 2 \\
\hline 50 & all & 57 & 66 & 66/Dec & 69 & 0 & 1 & 2 \\
\hline 51 & all & 58 & 66/Dec & 67 & 70 & 1 & 2 & 2 \\
\hline 52 & all & 59 & 67 & 68 & 71 & 2 & 2 & 2 \\
\hline 53 & all & 60 & 68 & 69 & 72 & 2 & 2 & 2 \\
\hline 54 & all & 61 & 69 & 70 & 73 & 2 & 2 & 2 \\
\hline 55 & all & 62 & 70 & 71 & 74 & 2 & 2 & 2 \\
\hline 56 & all & 63 & 71 & 72 & 75 & 2 & 2 & 2 \\
\hline 57 & all & 64 & 72 & 73 & 76 & 2 & 2 & 2 \\
\hline 58 & all & 65 & 73 & 74 & 77 & 2 & 2 & 2 \\
\hline 59 & all & 66 & 74 & 75 & 78 & 2 & 2 & 2 \\
\hline 60 & 1 & 66/Dec & 75 & 76 & 79 & 1 & 1 & 1 \\
\hline 60 & 2 & 66/Dec & 75 & 76 & 79 & 1 & 1 & 1 \\
\hline 60 & 3 & 67 & 76 & 77 & 80 & 0 & 0 & 0 \\
\hline 60 & 4 & 67 & 76 & 77 & 80 & 0 & 0 & 0 \\
\hline
\end{tabular}

Note: This table shows years of school entry and graduation based on school entry in the year after the $6^{\text {th }}$ birthday, no grade repetition, and 9 years of basic school. 
Table 2

Percentage of Respondents Who Have Lived in Current State Since Specific Age or Time ALLBUS, 1991, 1992, 1994, and 2000 Waves

Has Lived in Current

State Since
State of Current Residence

Berlin/ Hamburg

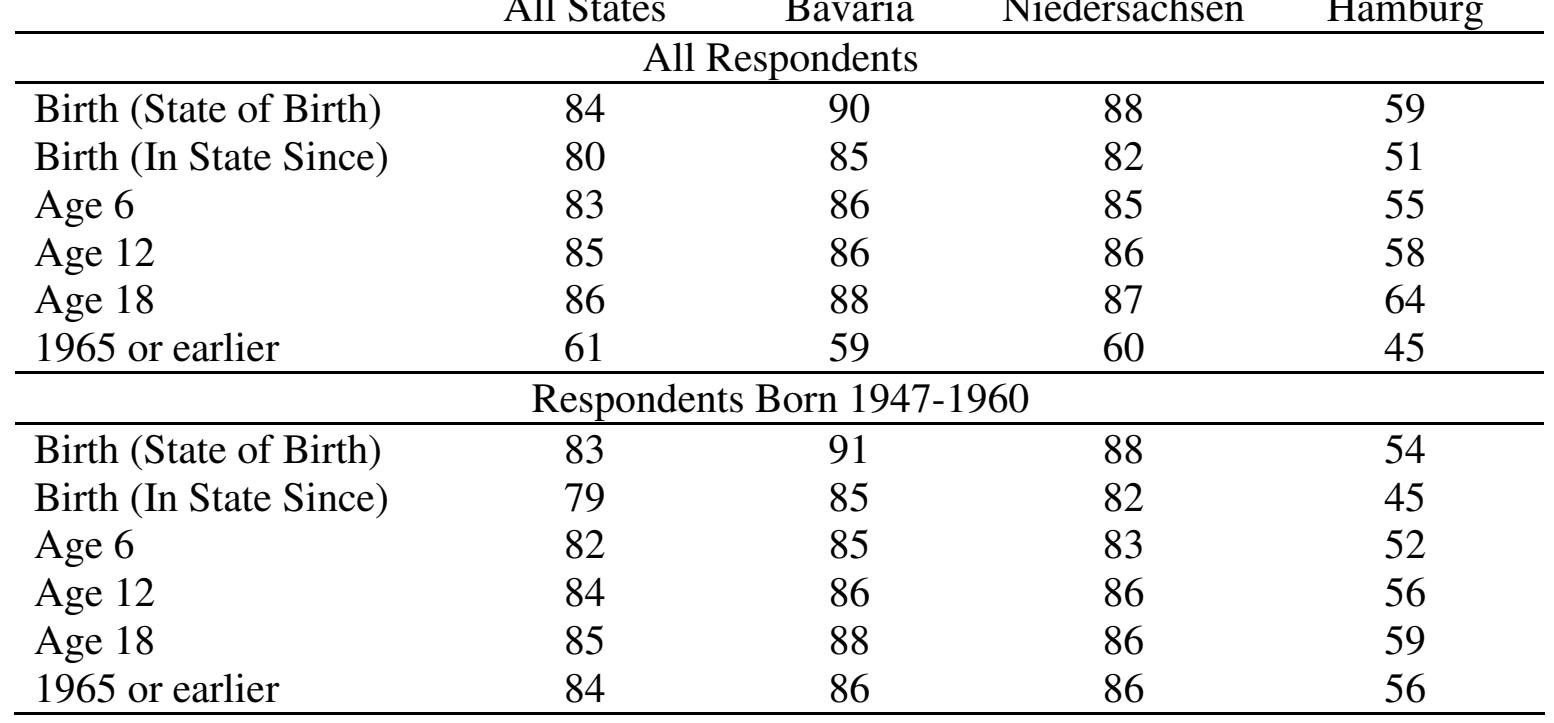

Note: The first row is based on whether state at birth is the same as state of current residence. The other rows are based on a question asking how long the respondent has lived in the state of current residence. Number of observations is 2445 for all states (1133 for respondents born 1947-60), 567 (237) for Bavaria, 273 (125) for Niedersachsen, and 148 (75) for Berlin/Hamburg. There are slightly fewer observations for the first row (respondent still in state of birth) in each case. 
Table 3

Test Results of Short School Year Students

(t-statistics in Parentheses)

\begin{tabular}{|c|c|c|c|c|c|c|}
\hline \multirow[b]{2}{*}{ Test } & \multirow[b]{2}{*}{ Mean of } & \multicolumn{2}{|c|}{$\begin{array}{c}\text { Control Groups } \\
\text { Tested After }\end{array}$} & \multicolumn{3}{|c|}{$\begin{array}{l}\text { Treatment Groups } \\
\text { Tested After }\end{array}$} \\
\hline & & Short & Regular & Short & Regular & $\begin{array}{l}2 \text { Years } \\
\text { Later }\end{array}$ \\
\hline \multicolumn{7}{|c|}{$2^{\text {nd }}$ graders (Meister, 1972) } \\
\hline Reading & Mistakes & 19.6 & & $\begin{array}{l}16.2 \\
(5.4)\end{array}$ & & \\
\hline Writing & Mistakes & 15.0 & & $\begin{array}{c}8.3 \\
(8.8)\end{array}$ & & \\
\hline Math & Mistakes & 16.3 & & $\begin{array}{c}6.7 \\
(11.3) \\
\end{array}$ & & \\
\hline \multicolumn{7}{|c|}{$2^{\text {nd }}$ graders (Thiel, 1973) } \\
\hline Writing & Mistakes & & 11.8 & $\begin{array}{l}13.5 \\
(1.5)\end{array}$ & $\begin{array}{c}8.5 \\
(3.9)\end{array}$ & \\
\hline Math & Correct Answers & & 27.0 & $\begin{array}{l}18.2 \\
(4.5)\end{array}$ & $\begin{array}{l}29.9 \\
(1.9)\end{array}$ & \\
\hline \multicolumn{7}{|c|}{$4^{\text {th }}$ graders (Thiel, 1973) } \\
\hline Reading & Correct Answers & & 12.7 & $\begin{array}{l}10.2 \\
(7.3)\end{array}$ & $\begin{array}{l}12.7 \\
(0.1)\end{array}$ & $\begin{array}{l}11.9 \\
(2.1)\end{array}$ \\
\hline Vocabulary & Correct Answers & & 19.8 & $\begin{array}{l}17.1 \\
(5.1)\end{array}$ & $\begin{array}{l}20.5 \\
(1.9)\end{array}$ & $\begin{array}{l}18.9 \\
(1.7)\end{array}$ \\
\hline Writing & $\begin{array}{l}\text { Correct } \\
\text { Answers }\end{array}$ & & 13.5 & $\begin{array}{l}14.1 \\
(1.6)\end{array}$ & $\begin{array}{l}15.4 \\
(6.8)\end{array}$ & $\begin{array}{l}14.0 \\
(0.9)\end{array}$ \\
\hline $\begin{array}{l}\text { Mental } \\
\text { Arithmetic }\end{array}$ & Correct Answers & & 9.5 & $\begin{array}{c}7.7 \\
(4.4)\end{array}$ & $\begin{array}{c}9.9 \\
(1.3)\end{array}$ & $\begin{array}{c}9.2 \\
(0.6)\end{array}$ \\
\hline $\begin{array}{l}\text { Written } \\
\text { Arithmetic }\end{array}$ & Correct Answers & & 11.3 & $\begin{array}{l}11.5 \\
(0.5)\end{array}$ & $\begin{array}{l}11.4 \\
(0.3)\end{array}$ & $\begin{array}{l}11.3 \\
(0.0)\end{array}$ \\
\hline Math Problems & $\begin{array}{l}\text { Correct } \\
\text { Answers } \\
\end{array}$ & & 11.2 & $\begin{array}{l}11.0 \\
(0.3) \\
\end{array}$ & $\begin{array}{l}12.3 \\
(3.3) \\
\end{array}$ & $\begin{array}{l}12.1 \\
(2.1)\end{array}$ \\
\hline \multicolumn{7}{|c|}{$4^{\text {th }}$ graders (Schlevoigt et al., 1968) } \\
\hline $\begin{array}{l}\text { Text } \\
\text { Comprehension }\end{array}$ & $\begin{array}{l}\text { Fraction } 12+ \\
\text { Points }(20 \text { total) }\end{array}$ & & 0.58 & $\begin{array}{l}0.54 \\
(2.7)\end{array}$ & & \\
\hline Writing & $\begin{array}{l}\text { Fraction }<12 \\
\text { Mistakes }\end{array}$ & & 0.55 & $\begin{array}{l}0.38 \\
(9.5)\end{array}$ & & \\
\hline Arithmetic & $\begin{array}{l}\text { Fraction } 20+ \\
\text { Points (30 total) }\end{array}$ & & 0.60 & $\begin{array}{l}0.57 \\
(2.0)\end{array}$ & & \\
\hline Math Problems & $\begin{array}{l}\text { Fraction } 10+ \\
\text { Points }(20 \text { total })\end{array}$ & & 0.59 & $\begin{array}{l}0.57 \\
(0.7) \\
\end{array}$ & & \\
\hline \multicolumn{7}{|c|}{$8^{\text {th }}$ graders in basic school track (Thiel, 1973) } \\
\hline Writing & Mistakes & & 17.9 & $\begin{array}{l}18.6 \\
(0.9)\end{array}$ & $\begin{array}{l}18.0 \\
(0.4)\end{array}$ & \\
\hline Math & Correct Answers & & 30.2 & $\begin{array}{l}32.9 \\
(0.9) \\
\end{array}$ & $\begin{array}{l}34.2 \\
(1.6) \\
\end{array}$ & \\
\hline
\end{tabular}

Notes: Fractions and t-statistics for Schlevoigt et al. (1968) are calculated by the author from the tabulated distribution of results. 


\section{Table 4}

\section{Fraction of Students Repeating Primary Grades 1966 to 1971 by State Group}

\begin{tabular}{|c|c|c|c|c|}
\hline & Grade 1 & Grade 2 & Grade 3 & Grade 4 \\
\hline \multicolumn{5}{|c|}{ 1965-66 School Year } \\
\hline States with Short School Years & 0.045 & 0.044 & 0.036 & 0.034 \\
\hline Bavaria & 0.036 & 0.026 & 0.020 & 0.014 \\
\hline States with Long School Years & 0.037 & 0.052 & 0.043 & 0.040 \\
\hline \multicolumn{5}{|c|}{ 1966-67 School Year $\left(2^{\text {nd }}\right.$ Short School Year $)$} \\
\hline States with Short School Years & 0.045 & 0.053 & 0.040 & 0.037 \\
\hline Bavaria & 0.038 & 0.026 & 0.021 & 0.015 \\
\hline States with Long School Years & 0.029 & 0.048 & 0.039 & 0.034 \\
\hline \multicolumn{5}{|c|}{ 1967-68 School Year } \\
\hline States with Short School Years & 0.047 & 0.057 & 0.046 & 0.043 \\
\hline Bavaria & 0.040 & 0.028 & 0.020 & 0.015 \\
\hline \multicolumn{5}{|c|}{ 1968-69 School Year } \\
\hline States with Short School Years & 0.048 & 0.049 & 0.049 & 0.048 \\
\hline Bavaria & 0.037 & 0.026 & 0.019 & 0.015 \\
\hline States with Long School Years & 0.034 & 0.043 & 0.028 & 0.030 \\
\hline \multicolumn{5}{|c|}{ 1969-70 School Year } \\
\hline States with Short School Years & 0.053 & 0.044 & 0.038 & 0.045 \\
\hline Bavaria & 0.038 & 0.027 & 0.018 & 0.016 \\
\hline States with Long School Years & 0.033 & 0.048 & 0.034 & 0.025 \\
\hline \multicolumn{5}{|c|}{ 1970-71 School Year } \\
\hline States with Short School Years & 0.053 & 0.042 & 0.032 & 0.032 \\
\hline Bavaria & 0.039 & 0.027 & 0.019 & 0.017 \\
\hline States with Long School Years & 0.034 & 0.044 & 0.032 & 0.027 \\
\hline
\end{tabular}

Source: Statistisches Bundesamt, Fachserie A. Bevölkerung und Kultur, Reihe 10, I, Allgemeines Bildungswesen, Stuttgart: Kohlhammer, various issues.

Note: States with short school years are Schleswig-Holstein, Bremen, Nordrhein-Westfalen, Hessen, Rheinland-Pfalz, Saarland, and Baden-Württemberg (Niedersachsen is excluded from this group), states with long school years are Berlin and Hamburg. Shaded areas indicate grades affected by the short school years. No Berlin data on grade repetition are available for the 196768 school year. 
Table 5

Fraction of Students Entering Gymnasium after Grade 4

1963 to 1971 by State Group

\begin{tabular}{lcccc} 
School Year & $\begin{array}{c}\text { States with } \\
\text { Short School } \\
\text { Years }\end{array}$ & Bavaria & Hamburg & Niedersachsen \\
\hline 1964 & 0.198 & 0.188 & 0.217 & 0.140 \\
1965 & 0.227 & 0.214 & 0.251 & 0.175 \\
1966 (start of 1 ${ }^{\text {st }}$ short school year) & 0.237 & 0.213 & 0.271 & 0.182 \\
1967 & 0.248 & 0.220 & 0.290 & 0.173 \\
1968 & 0.256 & 0.220 & 0.395 & 0.183 \\
1969 & 0.273 & 0.231 & 0.405 & 0.162 \\
1971 & 0.289 & 0.266 & 0.380 & 0.225 \\
\hline
\end{tabular}

Source: Statistisches Bundesamt, Fachserie A. Bevölkerung und Kultur, Reihe 10, I, Allgemeines Bildungswesen, Stuttgart: Kohlhammer, various issues.

Note: States with short school years are Schleswig-Holstein, Nordrhein-Westfalen, RheinlandPfalz, Saarland, and Baden-Württemberg (Bremen, Hessen and Niedersachsen are excluded from this group). Shaded area indicates grades affected by the short school years. 
Table 6

Regression Estimates of the Effect of the Short School Years on Grade Repetition and Secondary School Track Choice

(Standard Errors in Parentheses)

Dependent Variable

\begin{tabular}{lcccc} 
& \multicolumn{3}{c}{ Grade Repetition } & Entered \\
\cline { 2 - 5 } Independent Variable/Specification & $(1)$ & $(2)$ & $(3)$ & $(4)$ \\
\hline Mean of Dependent Variable & 0.0389 & 0.0389 & 0.0372 & 0.237 \\
\hline Affected by Short School Years & 0.0078 & 0.0067 & 0.0070 & 0.004 \\
(Niedersachsen is Treatment) & $(0.0018)$ & $(0.0017)$ & $(0.0021)$ & $(0.011)$ \\
Affected by Short School Years & 0.0088 & 0.0094 & 0.0109 & 0.017 \\
(Niedersachsen is Control) & $(0.0017)$ & $(0.0016)$ & $(0.0019)$ & $(0.009)$ \\
Affected by Short School Years & 0.0096 & 0.0088 & 0.0096 & 0.010 \\
(Sample without Niedersachsen ) & $(0.0013)$ & $(0.0011)$ & $(0.0012)$ & $(0.011)$ \\
Year Dummies & $\checkmark$ & $\checkmark$ & $\checkmark$ & $\checkmark$ \\
State Dummies & $\checkmark$ & $\checkmark$ & $\checkmark$ & $\checkmark$ \\
Grade Dummies & $\checkmark$ & $\checkmark$ & $\checkmark$ & \\
State*Grade Interactions & & $\checkmark$ & $\checkmark$ & 70 \\
\hline Number of Observations & 256 & 256 & 192 & \\
\hline
\end{tabular}

Note: States with short school years are Schleswig-Holstein, Bremen, Nordrhein-Westfalen, Hessen, Rheinland-Pfalz, Saarland, and Baden-Württemberg. Niedersachsen is treated differently in different specifications. Data on grade repetition cover grades 1 to 4 and the school years ending 1966 to 1971. Berlin data are missing for the 1967-68 school year. The regressions are weighted by the number of students in each grade, year, and state. Column (3) only includes grades 2 to 4 . Data on entering gymnasium cover the years 1964 to1971, Bremen and Berlin are excluded, and there are missing observations for Hessen in 1969 and Hamburg, Niedersachsen, Baden-Württemberg and Bavaria in 1970. The regressions are weighted by the number of fourth graders in the year and state. 
Table 7

Earnings Regressions

Qualification and Career Survey

Cohorts Born 1943-64

(Standard Errors in Parentheses)

\begin{tabular}{|c|c|c|c|c|}
\hline Independent Variable & $\begin{array}{l}\text { OLS } \\
(1)\end{array}$ & $\begin{array}{l}\text { OLS } \\
(2)\end{array}$ & $\begin{array}{l}\text { IV } \\
(3)\end{array}$ & $\begin{array}{c}\text { Only Men } \\
\text { OLS } \\
(4)\end{array}$ \\
\hline \multicolumn{5}{|c|}{ Dependent Variable: Log Hourly Wage } \\
\hline $\begin{array}{l}\text { Short School Year } \\
\text { Definition Based on Tracks }\end{array}$ & $\begin{array}{l}-0.003 \\
(0.013)\end{array}$ & --- & $\begin{array}{c}0.005 \\
(0.014)\end{array}$ & $\begin{array}{c}0.009 \\
(0.015)\end{array}$ \\
\hline $\begin{array}{l}\text { Short School Year } \\
\text { Definition Based on Graduation Date }\end{array}$ & --- & $\begin{array}{c}0.004 \\
(0.012)\end{array}$ & --- & --- \\
\hline \multicolumn{5}{|c|}{ Dependent Variable: Log Monthly Earnings } \\
\hline $\begin{array}{l}\text { Short School Year } \\
\text { Definition Based on Tracks }\end{array}$ & $\begin{array}{l}-0.001 \\
(0.015)\end{array}$ & --- & $\begin{array}{c}0.009 \\
(0.016)\end{array}$ & $\begin{array}{c}0.016 \\
(0.017)\end{array}$ \\
\hline $\begin{array}{l}\text { Short School Year } \\
\text { Definition Based on Graduation Date }\end{array}$ & --- & $\begin{array}{c}0.007 \\
(0.013)\end{array}$ & --- & --- \\
\hline Secondary School Track Dummies & $\checkmark$ & $\checkmark$ & $\checkmark$ & $\checkmark$ \\
\hline Year Dummies & $\checkmark$ & $\checkmark$ & $\checkmark$ & $\checkmark$ \\
\hline State of Residence Dummies & $\checkmark$ & $\checkmark$ & $\checkmark$ & $\checkmark$ \\
\hline Year of Birth Dummies & $\checkmark$ & $\checkmark$ & $\checkmark$ & $\checkmark$ \\
\hline Age Dummies & $\checkmark$ & $\checkmark$ & $\checkmark$ & $\checkmark$ \\
\hline Female Dummy & $\checkmark$ & $\checkmark$ & $\checkmark$ & $\checkmark$ \\
\hline Number of Observations & 45521 & 45521 & 45521 & 26990 \\
\hline
\end{tabular}

Note: Standard errors are adjusted for clusters at the track * year of birth * state level. The short school year measure based on graduation date is used as an instrument for the short school year measure based on tracks in column (3). 
Table 8

Earnings Regressions

Qualification and Career Survey

(Standard Errors in Parentheses)

\begin{tabular}{lcccc} 
& Primary & & & Secondary \\
Cohorts Affected in & School & Grades 1-9 & School \\
& $1943-46$ & \multicolumn{2}{c}{$1943-46$} & $1943-55$ \\
Cohorts & $1957-64$ & \multicolumn{2}{c}{$1952-64$} & $1961-64$ \\
\cline { 2 - 4 } Independent Variable & $(1)$ & $(2)$ & $(3)$ & $(4)$ \\
\hline \multicolumn{4}{c}{ Dependent Variable: Log Hourly Wage } & \\
\hline Short School Year & 0.009 & -0.001 & 0.027 & -0.009 \\
Definition Based on Tracks & $(0.017)$ & $(0.014)$ & $(0.048)$ & $(0.016)$ \\
\hline \multicolumn{4}{c}{ Dependent Variable: Log Monthly Earnings } & \\
\hline Short School Year & -0.007 & -0.011 & 0.010 & 0.001 \\
Definition Based on Tracks & $(0.020)$ & $(0.016)$ & $(0.050)$ & $(0.018)$ \\
Secondary School Track Dummies & $\checkmark$ & $\checkmark$ & & $\checkmark$ \\
Year Dummies & $\checkmark$ & $\checkmark$ & $\checkmark$ & $\checkmark$ \\
State of Residence Dummies & $\checkmark$ & $\checkmark$ & $\checkmark$ & $\checkmark$ \\
Year of Birth Dummies & $\checkmark$ & $\checkmark$ & $\checkmark$ & $\checkmark$ \\
Age Dummies & $\checkmark$ & $\checkmark$ & $\checkmark$ & $\checkmark$ \\
Female Dummy & $\checkmark$ & $\checkmark$ & $\checkmark$ & $\checkmark$ \\
\hline Number of Observations & 23632 & 35113 & 32040 & 33660 \\
\hline
\end{tabular}

Note: Standard errors are adjusted for clusters at the track * year of birth * state level. Observations from Niedersachsen are omitted from the specification in column (3). 
Table 9

Earnings Regressions

ALLBUS 1980-2000

Dependent Variable: Log Monthly Earnings

(Standard Errors in Parentheses)

\begin{tabular}{lcccc} 
Waves & All & \multicolumn{2}{c}{$1991,1992,1994$, and 2000} \\
Independent Variable & $(1)$ & $(2)$ & $(3)$ & $(4)$ \\
\hline Short School Year & -0.018 & -0.005 & -0.005 & -- \\
Definition Based on State of Residence & $(0.033)$ & $(0.070)$ & $(0.071)$ & \\
Short School Year & & & & 0.041 \\
Definition Based on State of Birth & --- & -- & -- & $(0.071)$ \\
Secondary School Track Dummies & $\checkmark$ & $\checkmark$ & $\checkmark$ & $\checkmark$ \\
Year Dummies & $\checkmark$ & $\checkmark$ & $\checkmark$ & $\checkmark$ \\
State of Residence Dummies & $\checkmark$ & $\checkmark$ & $\checkmark$ & $\checkmark$ \\
State of Birth Dummies & & & $\checkmark$ & $\checkmark$ \\
Year of Birth Dummies & $\checkmark$ & $\checkmark$ & $\checkmark$ & $\checkmark$ \\
Age Dummies & $\checkmark$ & $\checkmark$ & $\checkmark$ & $\checkmark$ \\
Female Dummy & $\checkmark$ & $\checkmark$ & $\checkmark$ & $\checkmark$ \\
\hline Number of Observations & 6215 & 1649 & 1649 & 1649 \\
\hline
\end{tabular}

Note: Samples include employed workers in cohorts born 1943-64. Standard errors are adjusted for clusters at the track* year of birth * state level. 
Table 10

Political Participation and Attitudes, Interest in Music

ALLBUS 1980-2000, various years

(Standard Errors in Parentheses)

\begin{tabular}{lccccc} 
Dependent Variable & $\begin{array}{c}\text { Would not } \\
\text { Vote Next } \\
\text { Sunday } \\
(1)\end{array}$ & $\begin{array}{c}\text { Did not } \\
\text { Vote Last } \\
\text { Election } \\
(2)\end{array}$ & $\begin{array}{c}\text { Little } \\
\text { Political } \\
\text { Interest } \\
(3)\end{array}$ & $\begin{array}{c}\text { Likes } \\
\text { Extreme } \\
\text { Party } \\
(4)\end{array}$ & $\begin{array}{c}\text { Member of } \\
\text { Choir, } \\
\text { Orchestra } \\
(5)\end{array}$ \\
\hline Mean of Dependent Variable & 0.061 & 0.098 & 0.226 & 0.058 & 0.036 \\
\hline Short School Year & -0.002 & 0.016 & -0.020 & 0.044 & -0.018 \\
Definition Based on State of Residence & $(0.017)$ & $(0.030)$ & $(0.030)$ & $(0.028)$ & $(0.012)$ \\
Secondary School Track Dummies & $\checkmark$ & $\checkmark$ & $\checkmark$ & $\checkmark$ & $\checkmark$ \\
Year Dummies & $\checkmark$ & $\checkmark$ & $\checkmark$ & $\checkmark$ & $\checkmark$ \\
State of Residence Dummies & $\checkmark$ & $\checkmark$ & $\checkmark$ & $\checkmark$ & $\checkmark$ \\
Year of Birth Dummies & $\checkmark$ & $\checkmark$ & $\checkmark$ & $\checkmark$ & $\checkmark$ \\
Age Dummies & $\checkmark$ & $\checkmark$ & $\checkmark$ & $\checkmark$ & $\checkmark$ \\
Female Dummy & $\checkmark$ & $\checkmark$ & $\checkmark$ & $\checkmark$ & $\checkmark$ \\
\hline Number of Observations & 6057 & 4477 & 5952 & 2029 & 6925 \\
\hline
\end{tabular}

Note: Samples include cohorts born 1943-64. Standard errors are adjusted for clusters at the track * year of birth * state level. 
Figure 1: Teacher Absences

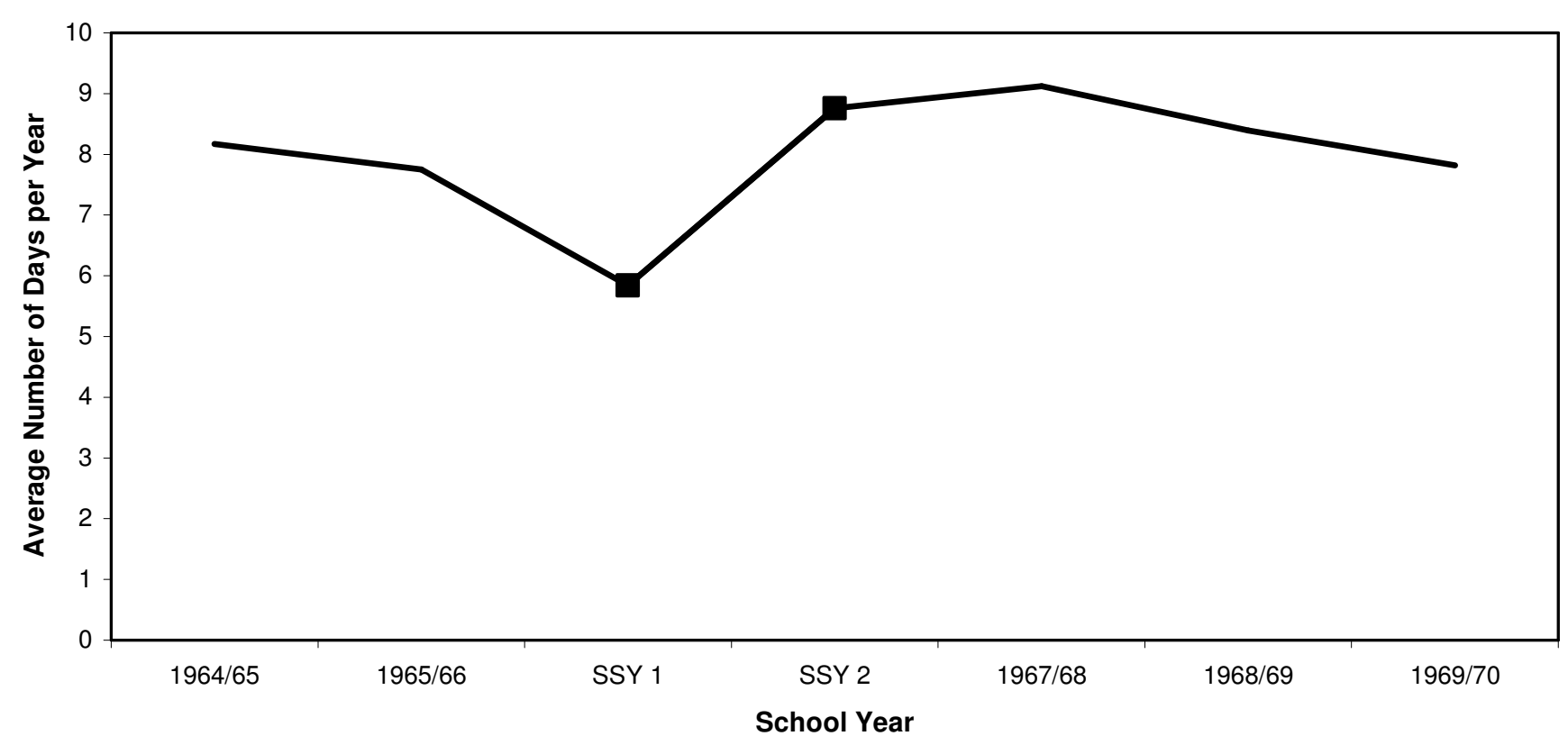

Figure 2: Grade Repetition Rates Grade 2

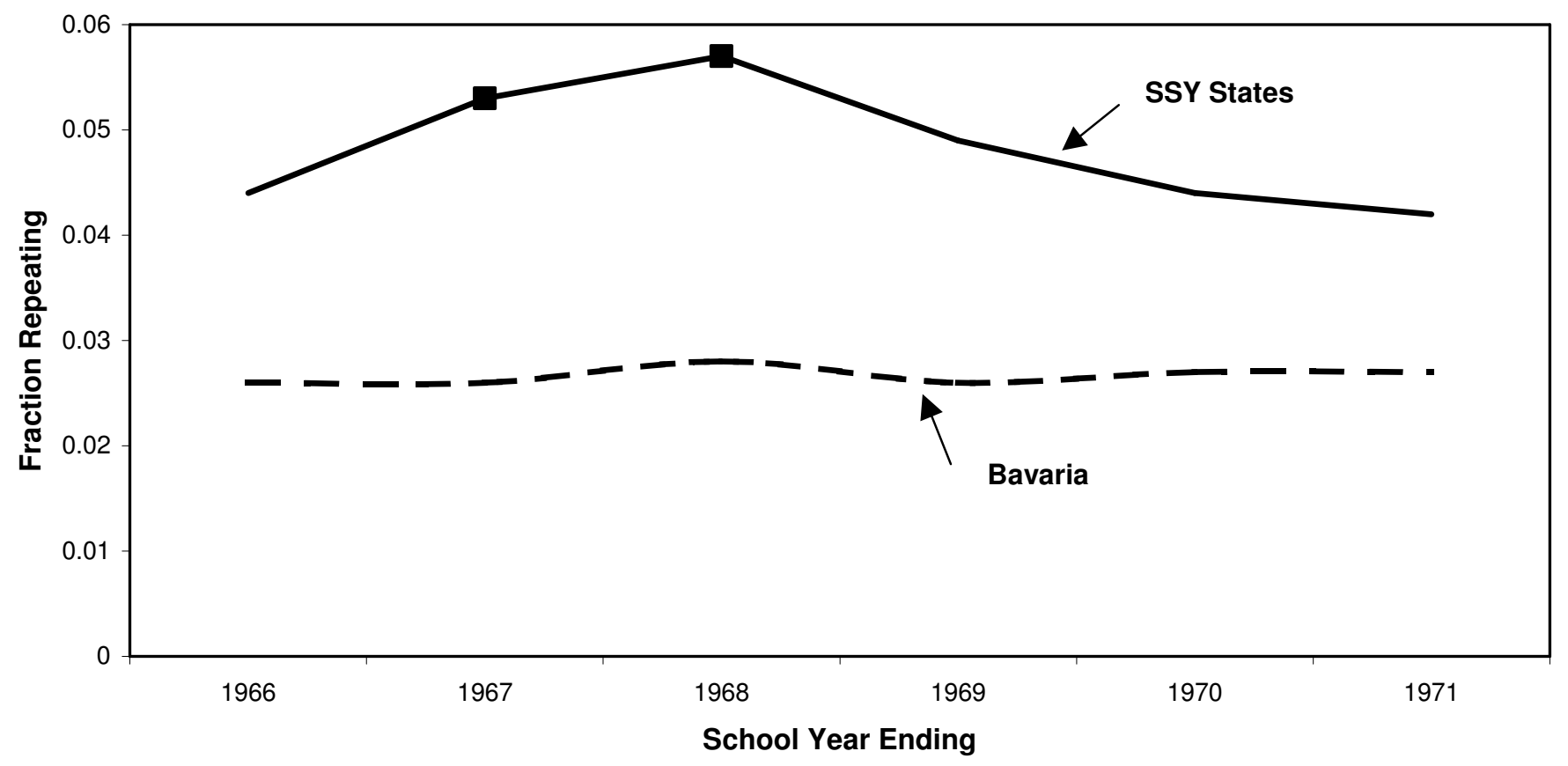


Figure 3: Grade Repetion Rates Grade 3

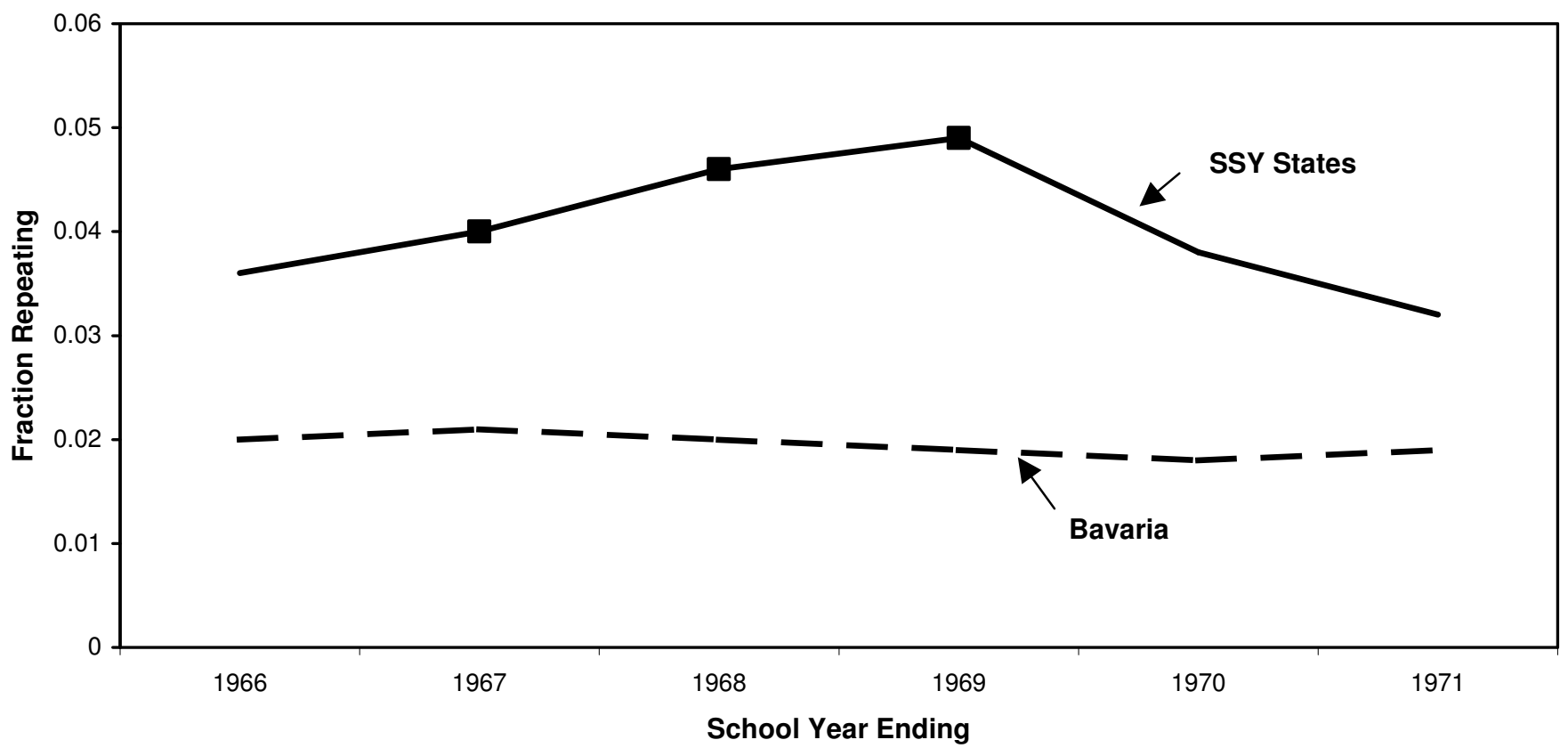

Figure 4: Grade Repetion Rates Grade 4

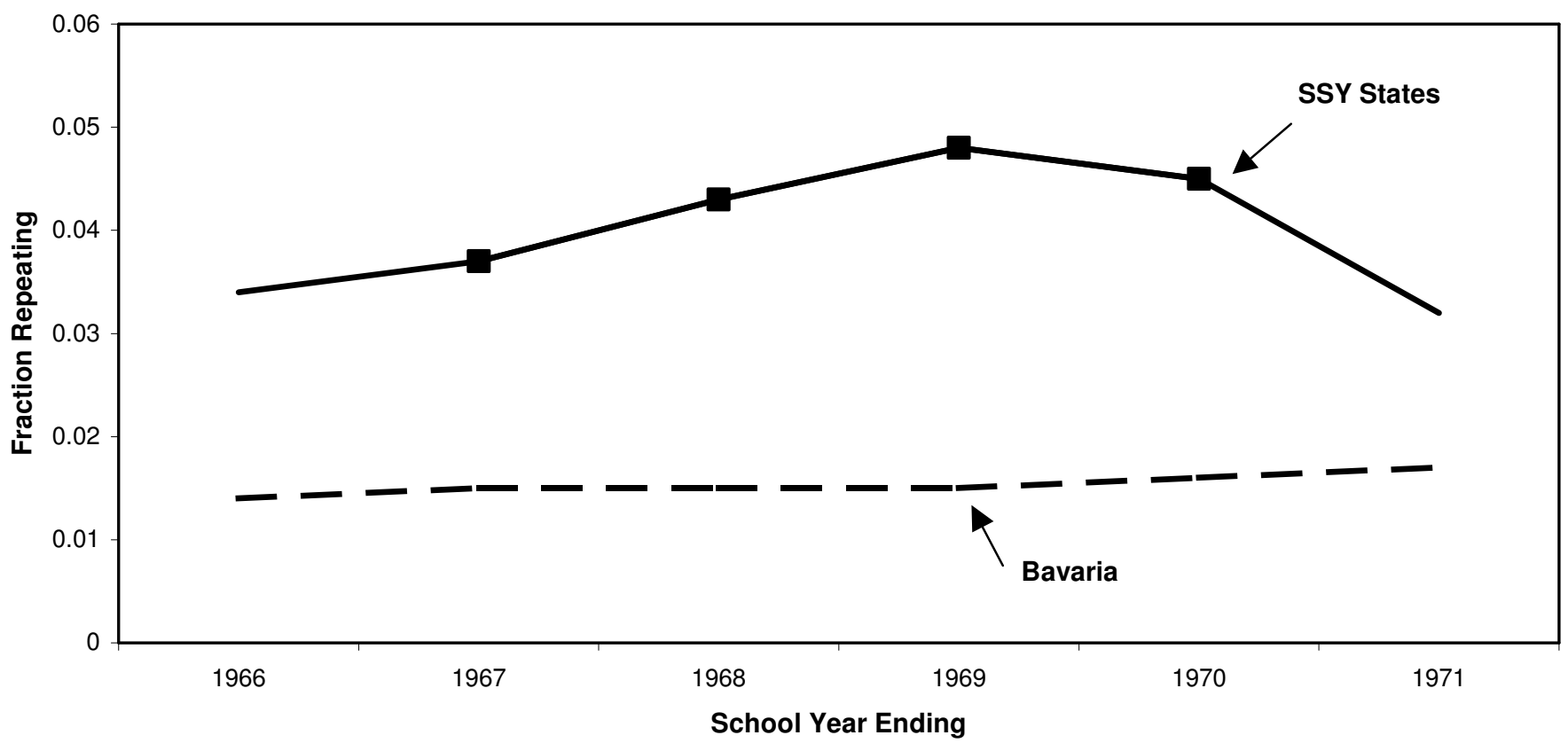


Figure 5: Earnings Effects of the Short School Years by Grade Qualification and Career Survey

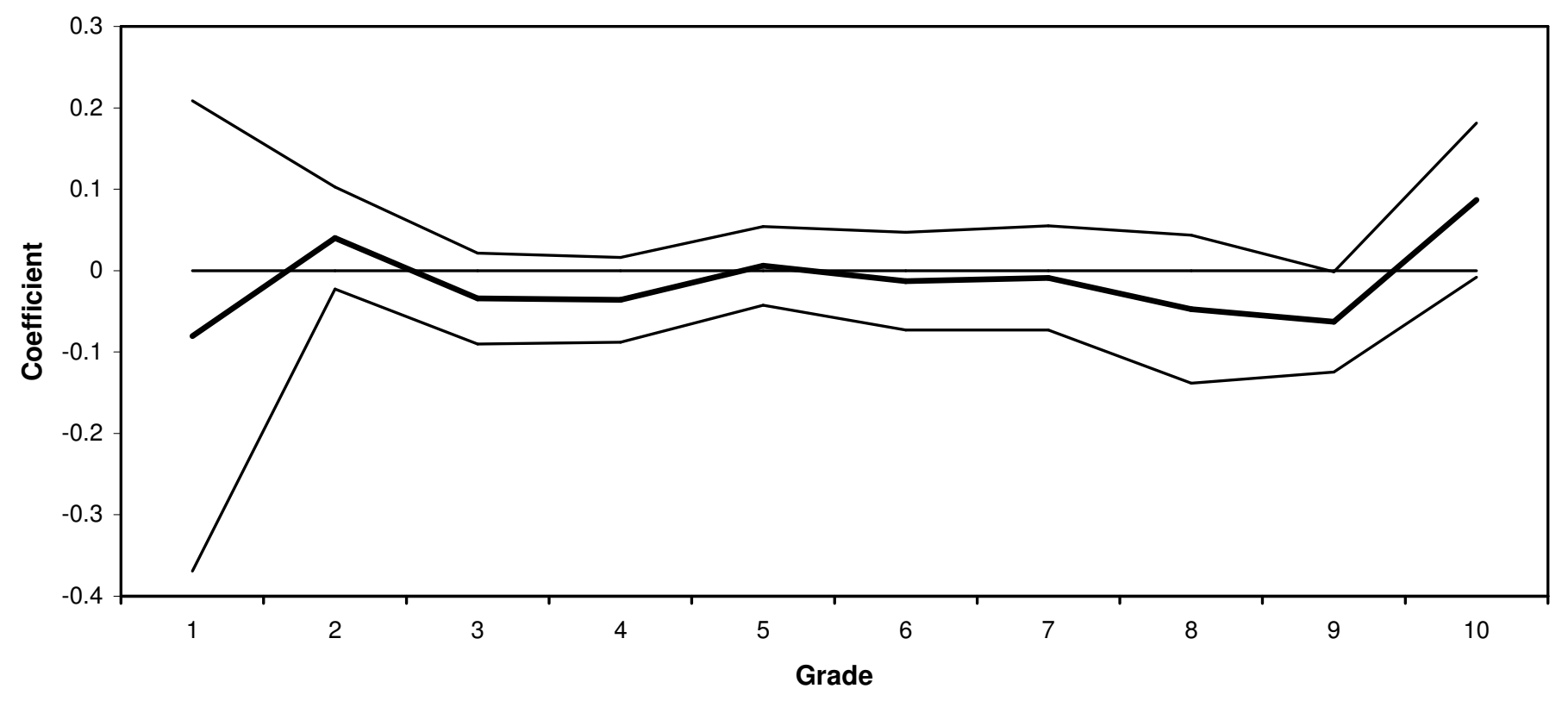

